\title{
Phylogeny and evolution of the Arctium-Cousinia complex (Compositae, Cardueae-Carduinae)
}

\author{
Sara López-Vinyallonga ${ }^{1,4 *}$, Iraj Mehregan ${ }^{2,4}$, Núria Garcia-Jacas ${ }^{1}$, Olga Tscherneva ${ }^{3}$, \\ Alfonso Susanna ${ }^{1}$ \& Joachim W. Kadereit ${ }^{2}$ \\ ${ }^{1}$ Botanical Institute of Barcelona (CSIC-ICUB), Pg. del Migdia s. n., 08038 Barcelona, Spain. *slopez@ibb. \\ csic.es (author for correspondence) \\ ${ }^{2}$ Johannes Gutenberg-Universität Mainz, Institut für Spezielle Botanik und Botanischer Garten, 55099 \\ Mainz, Germany \\ ${ }^{3}$ Komarov Botanical Institute, Ul. Prof. Popova 2, 197376 St. Petersburg, Russia \\ ${ }^{4}$ These authors contributed equally to this publication
}

\begin{abstract}
The phylogeny and evolution of the Arctium-Cousinia complex, including Arctium, Cousinia as one of the largest genera of Asteraceae, Hypacanthium and Schmalhausenia, is investigated. This group of genera has its highest diversity in the Irano-Turanian region and the mountains of Central Asia. We generated ITS and rpS4-trnT-trnL sequences for altogether 138 species, including 129 (of ca. 600) species of Cousinia. As found in previous analyses, Cousinia is not monophyletic. Instead, Cousinia subgg. Cynaroides and Hypacanthodes with together ca. 30 species are more closely related to Arctium, Hypacanthium and Schmalhausenia (Arctioid clade) than to subg. Cousinia (Cousinioid clade). The Arctioid and Cousiniod clades are also supported by pollen morphology and chromosome number as reported earlier. In the Arctioid clade, the distribution of morphological characters important for generic delimitation, mainly leaf shape and armature and morphology of involucral bracts, are highly incongruent with phylogenetic relationships as implied by the molecular data. No taxonomic solution for this conflict can be offered, and the characters named are interpreted as homoplasious. Although phylogenetic resolution in the Cousinioid clade is poor, our ITS and rpS4-trnT-trnL sequences contain some phylogenetic information. For example, the six annual species of the Cousinioid clade fall into two groups. Poor phylogenetic resolution probably results from lack of characters and the high number of taxa in this species-rich and comparatively young (ca. 8.7 mya) lineage. We hypothesize that speciation in the Cousinioid clade was mainly allopatric.
\end{abstract}

KEYWORDS: Arctium, Cousinia, Irano-Turanian region, ITS, molecular clock, Pamir-Alay, rpS4-trnTtrnL, speciation, Tien Shan

\section{INTRODUCTION}

The Arctium-Cousinia complex (Compositae, Cardueae-Carduinae) in its most recent circumscription (Susanna \& Garcia-Jacas, 2007) is a natural group composed of four genera. The largest genus of the group, one of the largest of the Compositae and among the 50 largest of flowering plants (Frodin, 2004), is Cousinia Cass. with more than 600 species (Mabberley, 2008). The other genera of the complex are Arctium L. (incl. part of Cousinia, see below) with 27 species, Hypacanthium Juz. with two species (Tscherneva, 1982) and the monotypic Schmalhausenia C. Winkl. Lipskyella Juz. and Tiarocarpus Rech.f., recognized as separate genera by Häffner (2000), were included in Cousinia by Susanna \& GarciaJacas (2007).

Three characters never found in combination elsewhere in the tribe characterize this complex according to Susanna \& al. (2003a). The receptacle has strongly twisted scales, the achenes are always streaky (with wavy fringes), very often winged and without a nectary, and the pappus is formed by free deciduous bristles.

According to Rechinger (1986) and Knapp (1987), the vast majority of species of the Arctium-Cousinia complex is distributed in the Turkestan mountain region (Tien Shan and Pamir-Alay) and the Irano-Turanian region (Fig. 1; the “Oriental-Turanian Floristic Region” of Meusel \& al., 1965). Within this range, following Knapp (1987), most species of Cousinia subgg. Cynaroides and Hypacanthodes grow only in the mountainous terrain of the Pamir-Alay range and in the western Tien Shan in Central Asia. The two species of Hypacanthium are endemic to the western Tien Shan, and the monotypic Schmalhausenia is endemic to the subalpine and alpine zone in the northern Tien Shan. Arctium s.str. is Eurosiberian in distribution. Those species of Cousinia included in Arctium by Duistermaat (1996) and Susanna \& Garcia-Jacas (2007; see below) are, like the remainder of Cousinia, distributed in Central Asia. 
Both morphological (Boissier, 1875; Kuntze, 1891; Dittrich, 1977; Tscherneva, 1988a-c; Duistermaat, 1996, 1997; Petit \& al., 1996; Petit, 1997; Häffner, 2000) and molecular (Häffner \& Hellwig, 1999; Garcia-Jacas \& al., 2002; Susanna \& al., 2003a, 2006) analyses of the Arctium-Cousinia complex concluded that the limits between the biennial Arctium and the perennial, biennial and only rarely annual Cousinia are unclear. This resulted in many reclassifications with many species changing generic affiliation. As one extreme, Kuntze (1891) proposed the classification of all species of Cousinia in Arctium.

The difficulties in generic delimitation arise from the incongruent distribution of several morphological, pollen, karyological and molecular characters.

Arctium has leaves which are always unarmed, often large (to $80 \mathrm{~cm}$ ), and usually cordate. Such leaves are also found in Cousinia subg. Cynaroides (with the exception of Cousinia korolkovii Regel \& Schmalh., C. haesitabunda Juz. and C. chlorantha Kult. with lanceolate leaves) and C. grandifolia Kult. of Cousinia subg. Hypacanthodes. This group of Cousinia species was referred to as the “Arctioid” group by Duistermaat (1996). In contrast, Cousinia subg. Cousinia, nine species of subg. Hypacanthodes, all species of Hypacanthium and the monotypic Schmalhausenia have smaller leaves which usually are lanceolate and often very spiny. In Arctium and part of Cousinia subg. Cynaroides involucral bracts always end in a recurved hook whereas in most other species of Cousinia involucral bracts end in an unhooked spine. Whereas in species with hooked involucral bracts usually the entire capitulum is dispersed as a burr adhering to passing animals, most species of Cousinia release their achenes and/ or disperse as tumbleweeds. As regards floral morphology, Duistermaat (1996) observed that the stigma of Cousinia subg. Cousinia is very different from that of Arctium and the "Arctioid" species of Cousinia. Whereas in the former the apical part of the style and the stylar branches are covered with long hairs, and a ring of sweeping hairs at the articulation of the base of the stylar apex is absent, the style is glabrous and cylindrical in the latter, and a ring of sweeping hairs is present at the thickened articulation. Häffner (2000) noted that a ring of sweeping hairs is also absent in Schmalhausenia. Outer florets in Arctium often have long and brightly coloured anther-tubes. Many species of Cousinia have brightly coloured appendages in the innermost involucral bracts, recalling those of Carlina L.

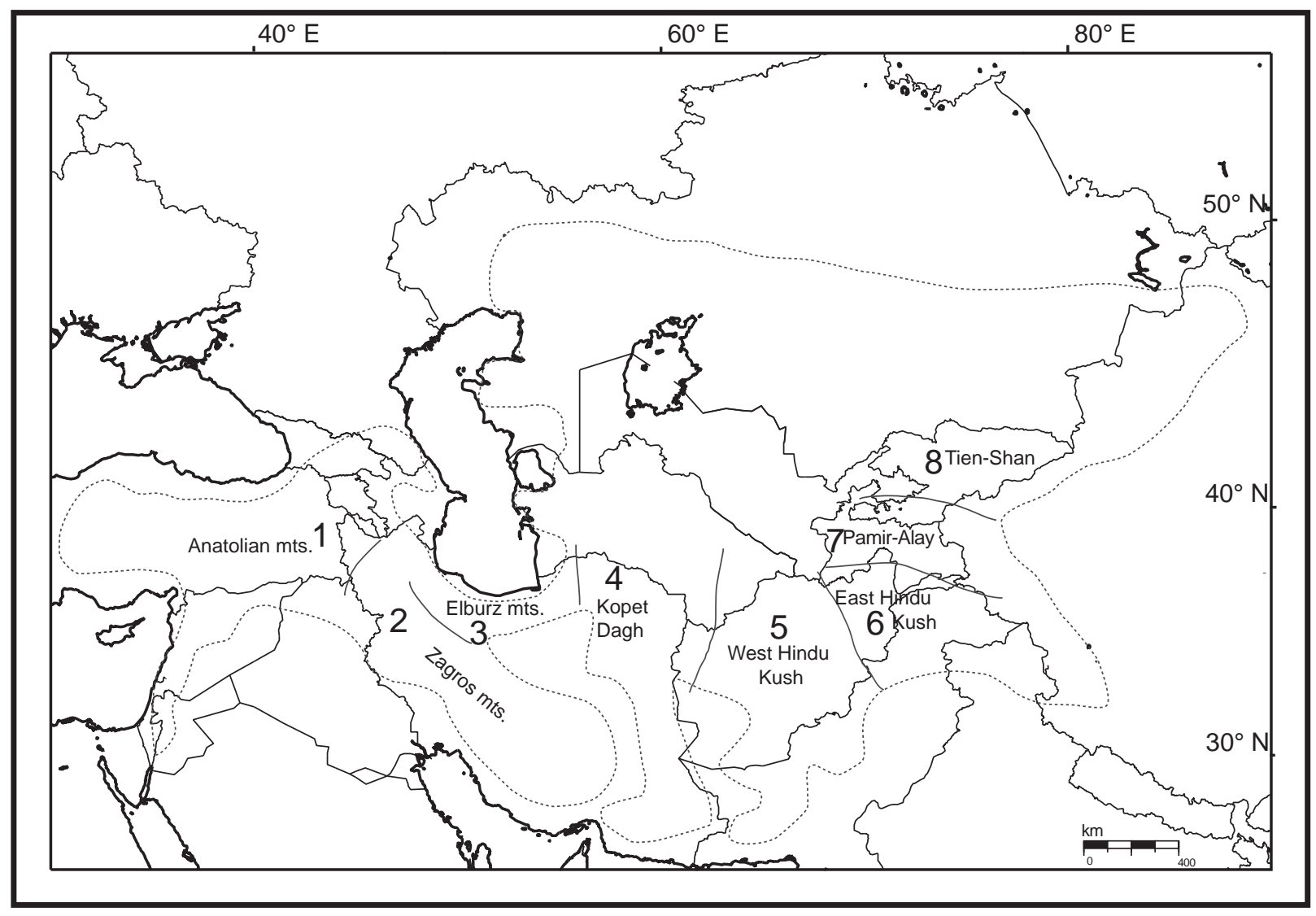

Fig. 1. Geographical distribution of the Arctium-Cousinia complex (excl. Arctium s.str.). The eight main centres of diversity recognized are based on Rechinger (1986) and Knapp (1987). 
This distribution of characters (leaf, involucral bract, style morphology) led Duistermaat (1996) to the conclusion that the obviously "Arctioid" species of Cousinia should be transferred to Arctium within which their sectional classification by Tscherneva (1988a-c) should be retained. However, later Duistermaat (1997) vaguely suggested that all species of Cousinia subg. Cynaroides could be placed in Arctium. This latter proposal was followed by Susanna \& Garcia-Jacas (2007) but does not solve the problematic placement of Hypacanthium, Schmalhausenia and Cousinia subg. Hypacanthodes.

Schtepa (1966, 1976) and Kuprianova \& Tscherneva (1982) found that Cousinia subgg. Cynaroides and Hypacanthodes have orbicular and spiny pollen grains similar to those of Arctium, which they called the Arctiastrum pollen type, whereas Cousinia subg. Cousinia has oblong and smooth pollen grains which they called the Cousinia pollen type. Schmalhausenia (Susanna \& al., 2003a) as well as Hypacanthium (S. López-Vinyallonga, unpub. data) have the Arctiastrum pollen type.

According to Duistermaat (1996), Arctium always has $x=18$ and $2 n=36$ chromosomes. This number is also found in all species studied of Cousinia subgg. Cynaroides and Hypacanthodes (Tscherneva, 1985) and in Schmalhausenia according to Susanna \& al. (2003b), and is perfectly correlated with the Arctiastrum pollen type. In contrast, Cousinia subg. Cousinia, with the Cousinia pollen type, has $2 n=18,20,22,24$ and 26 chromosomes according to Ghaffari \& al. (2006) and earlier authors. Finally, a DNA sequence analysis by Susanna \& al. (2003a) grouped all species with $2 n=36$ chromosomes and the Arctiastrum pollen type in a monophyletic clade, the Arctioid clade, and species with $2 n=22,24$ and 26 and the Cousinia pollen type in a second monophyletic clade, the Cousinioid clade.

In summary, pollen morphology, chromosome number and DNA data imply a subdivision of the ArctiumCousinia complex into two major lineages which are not congruent with overall morphology particularly because parts of Cousinia subgg. Cynaroides and Hypacanthodes (Arctioid clade) are more similar to subg. Cousinia (Cousinioid clade), and other parts (the Arctioid species) are more similar to Arctium.

Of the genera and lineages introduced above, Cousinia subg. Cousinia is most remarkable by containing a high number of species in a comparatively small geographical area. After establishment of Cousinia by Cassini (1827), Candolle (1838) recognized 34 species, Bunge (1865) 126 species, Boissier $(1875,1888) 141$ species (in the Flora Orientalis area), Winkler (1892, 1897) 267 species, and an additional 30 species were added in several publications by Bornmüller (1896-1941; listed by Rechinger, 1953). In her treatment of Cousinia for the Flora of the USSR, Tscherneva (1962) recognized about 262 species in about 50 sections, and in his treatment of the genus for Flora Iranica, Rechinger (1972) placed more than 350 species in 58 sections. A careful comparison of the systems of Rechinger $(1953,1972,1979)$ and Tscherneva $(1962,1988 a, b)$ reveals an approximate number of ca. 630 species in 70 sections and three subgenera. Of these 630 species, ca. 600 belong into subg. Cousinia.

The molecular analysis of the Arctium-Cousinia complex by Susanna \& al. (2003a) included 21 species of Cousinia subg. Cousinia, 1 species of subg. Hypacanthodes and 5 species of subg. Cynaroides. By increasing the sample of Cousinia subg. Cousinia to 106 species (of ca. 600), of subg. Hypacanthodes to 6 species (of 10) and of subg. Cynaroides to 14 species (of 20), where the sample included represents the large majority of subgeneric units recognized by Tscherneva (1962, 1988c) and Rechinger (1953, 1972, 1979), we pursue several aims. First, we want to investigate whether the subdivision of the ArctiumCousinia complex into two lineages, the Arctioid clade with Arctium s.str., Cousinia subgg. Hypacanthodes and Cynaroides, Hypacanthium and Schmalhausenia, and the Cousinioid clade with Cousinia subg. Cousinia as found by Susanna \& al. (2003a) and as supported by pollen morphology, chromosome number and DNA sequence data can be verified with a strongly enlarged species sample. Second, we aim at obtaining a better understanding of phylogenetic relationships within the Arctioid clade in order to resolve the character incongruences discussed above and to arrive at a new generic classification of this clade. Third, we want to investigate phylogenetic relationships within the large subg. Cousinia. The last aims both at examining the validity of the sectional (and subsectional) classification of this group as proposed by Tscherneva (1962, 1988a, b) and Rechinger (1953, 1972, 1979), and at providing a basis for discussing possible evolutionary mechanisms underlying the species-richness of subg. Cousinia.

\section{MATERIAL AND METHODS}

Plant material. - Samples for analysis were obtained either from silica-gel dried leaves of specimens collected in the wild, from fresh plants cultivated at the Botanic Institute of Barcelona, or from herbarium specimens deposited mainly in B, BC, JE, KAS, LE, M, and MJG (Appendix 1). The data described and discussed here are based on a sample of 138 species for which both ITS and rpS4-trnT-trnL could be obtained. These 138 species represent 60 sections of Cousinia (out of 70 described by Rechinger, 1972, 1979, and Tscherneva, 1988a-c), three species of Arctium and one each of Hypacanthium and Schmalhausenia. Four outgroup taxa were selected on the basis of previous analyses of the group (Garcia-Jacas 
\& al., 2002; Susanna \& al., 2006). These were Saussurea elegans Ledeb., S. maximowiczii Herder, Jurinea albicaulis Bunge and J. humilis (Desf.) DC. Eighty additional species were sequenced for ITS and 19 for rpS4-trnTtrnL. Results obtained for this additional sample are not presented and discussed only briefly. Voucher data and sources of material of the above 138 species are given in Appendix 1. Some of the ITS sequences were taken from previous studies but all rpS4-trnT-trnL sequences were newly generated.

DNA extraction, amplification and sequencing. - Total genomic DNA was extracted either following the protocol of the CTAB method of Doyle \& Doyle (1987) and Culling (1992), or following the manufacturer's protocols of the NucleoSpin ${ }^{\circledR}$ Plant Kit (Macherey-Nagel GmbH \& Co. KG, Düren, Germany) or QIAprep ${ }^{\circledR}$ Miniprep (Qiagen Inc., Valencia, California, U.S.A.).

nrDNA ITS. - Double-stranded DNA of the internal transcribed spacer region (ITS1, 5.8S, ITS2) was amplified using $18 \mathrm{~S}$ as forward primer and $28 \mathrm{~S}$ as reverse primer (Muir \& Schlötterer, 1999). Reactions were performed in $25.0 \mu \mathrm{l}$ volumes with $10 \% 10 \times$ Biotherm buffer, $5 \%$ $50 \mathrm{mM} \mathrm{MgCl}_{2}$ (GeneCraft, Münster, Germany), 2\% of $20 \mathrm{mM}$ dNTPs mix, $2 \%$ of each primer at $25 \mathrm{pmol} / \mu \mathrm{l}$ conc., 1.0 unit $(0.2 \mu \mathrm{l})$ BioTherm ${ }^{\mathrm{TM}}$ polymerase (GeneCraft) and $1.0 \mu \mathrm{l}$ of template DNA (30-60 ng/ $\mu \mathrm{l})$. This was filled up to $25.0 \mu \mathrm{l}$ with distilled sterilized water. In some cases $1.0 \mu \mathrm{l}$ DMSO (dimethyl sulfoxide) per reaction tube was added to improve PCR amplifications (Frackman \& al., 1998). The profile used for amplifications consisted of a preheat for $60 \mathrm{~s}$ at $94^{\circ} \mathrm{C}$, followed by 35 cycles of $94^{\circ} \mathrm{C}$ for $18 \mathrm{~s}, 52^{\circ} \mathrm{C}$ for $30 \mathrm{~s}$, and $72^{\circ} \mathrm{C}$ for $60 \mathrm{~s}$ and a post-treatment of $78 \mathrm{~s}$ at $52^{\circ} \mathrm{C}$ plus $8 \mathrm{~min}$ at $72^{\circ} \mathrm{C}$. PCR products were purified using the NucleoSpin ${ }^{\circledR}$ Extract Kit (Macherey-Nagel, Düren, Germany) following the manufacturer's protocol.

Cycle sequencing reactions were conducted using $0.5-2.5 \mu \mathrm{l}$ of the purified PCR product and ABI-PRISM ${ }^{\circledR}$ BigDye $^{\mathrm{TM}}$ Terminators v3.0 Cycle Sequencing Reagents (BD 3.0 in $10 \mathrm{ml}$ reactions) for 30 cycles for $10 \mathrm{~s}$ at $96^{\circ} \mathrm{C}$ and $4 \mathrm{~min}$ at $55^{\circ} \mathrm{C}$. Sequences were detected on automated sequencers (ABI 373 or 377 ).

For sequence analysis, ITS fragments were edited and assembled with the aid of Sequencher 4.1.2 (Gene Codes Corporation, Ann Arbor, Michigan, U.S.A.). Edited sequences were aligned with MacClade 4.1 (Maddison \& Maddison, 2000).

cpDNA rpS4-trnT-trnL. - The double-stranded DNA intergenic spacer rpS4-trnT-trnL was amplified by PCR with rpS4R2 (Shaw \& al., 2005), trnL-b (Taberlet \& al., 1991), trnA2 (Cronn \& al., 2002) and trnA2R (5'-AGG TTA GAG CAT CGC ATT TG-3' designed for this study) as PCR primers. When the rpS4R2 (forward)/ trnL-b (reverse) primer combination failed to generate double-stranded products, two separate PCR reactions were performed with the following primer combinations: rpS4R2/trnA2R (reverse) and trnA2(forward)/trnL-b. Reactions were performed in $25.0 \mu \mathrm{l}$ volumes with $10 \%$ 10× AmpliTaq buffer, $10 \% 50 \mathrm{mM} \mathrm{MgCl}_{2}, 10 \%$ of $20 \mathrm{mM}$ dNTPs mix, $2 \%$ of each primer at $25 \mathrm{pmol} / \mu \mathrm{l}$ conc., 1.0 unit $(0.2 \mu \mathrm{l})$ AmpliTaq DNA polymerase (Applied Biosystems, Foster City, California, U.S.A.), and $5.0 \mu \mathrm{l}$ of template DNA (30-60 ng/ $\mu \mathrm{l})$. The volume was filled up to $25.0 \mu \mathrm{l}$ with distilled sterilized water. The profile used for amplification consisted of a preheat for $1 \mathrm{~min} 35 \mathrm{~s}$ at $95^{\circ} \mathrm{C}$, followed by 35 cycles of $95^{\circ} \mathrm{C}$ for $1 \mathrm{~min} 30 \mathrm{~s}, 52^{\circ} \mathrm{C}$ for $1 \mathrm{~min} 30 \mathrm{~s}$ and $72^{\circ} \mathrm{C}$ for 2 min and a post-treatment of $10 \mathrm{~min}$ at $72^{\circ} \mathrm{C}$.

Double-stranded PCR products were purified with either the QIAquick ${ }^{\circledR}$ Purification Kit (Qiagen Inc., Valencia, California, U.S.A.) or DNA Clean \& Concentrator-5 (Zymo Research, Orange, California, U.S.A.) following the manufacturer's protocols. Direct sequencing of the amplified DNA segments was performed using 0.5-1.0 $\mu \mathrm{l}$ of the purified PCR product with a "Big Dye ${ }^{\circledR}$ Terminator v3.1 kit” (Applied Biosystems, Foster City, California, U.S.A.). The profile used consisted of a hot start at $96^{\circ} \mathrm{C}$ for $1 \mathrm{~min}$ followed by 25 cycles of $10 \mathrm{~s}$ at $96^{\circ} \mathrm{C}$, $5 \mathrm{~s}$ at $50^{\circ} \mathrm{C}$ and $4 \mathrm{~min}$ at $60^{\circ} \mathrm{C}$. Nucleotide sequencing was performed at the Serveis Científico-Tècnics of the University of Barcelona on an ABI PRISM 3700 DNA analyzer (Applied Biosystems, Foster City, California, U.S.A.). Nucleotide sequences were edited with Chromas 2.0 (Technelysium Pty. Ltd., Tewantin, Australia) and aligned visually by sequential pairwise comparison (Swofford \& Olsen, 1990).

Data matrices are available on request from the corresponding author.

Analyses. - Bayesian Inference. - Bayesian analyses of the ITS1 + ITS2, rpS4-trnT-trnL and combined ITS1 + ITS2 + rpS4-trnT-trnL datasets were performed with MrBayes software package 3.0b4 (Huelsenbeck \& Ronquist, 2001). Bayesian analyses consist of maximum likelihood (ML) comparisons of trees where tree topology and ML parameters are permuted using a Markov Chain Monte Carlo method and sampled periodically. The sample trees are drawn from a posterior probability distribution (Huelsenbeck \& Ronquist, 2001). In order to select the best-fit model of substitution, the program Modeltest 3.5 was used (Posada \& Crandall, 1998, 2001).

Following the results for DNA evolution of our data as indicated by ModelTest, the ML parameters in MrBayes were set as follows: Nst $=6$, Rmat $=$ for ITS dataset: A-C $=0.7720, \mathrm{~A}-\mathrm{G}=2.7242, \mathrm{~A}-\mathrm{T}=1.2057, \mathrm{C}-\mathrm{G}=0.3372$, $\mathrm{C}-\mathrm{T}=9.8048, \mathrm{G}-\mathrm{T}=1.0000$ (Proportion of invariable sites [I] = 0.1915; Gamma distribution shape parameter $=0.6024$; Model selected: SYM + I + G); for rpS4-trnT$\operatorname{trnL}$ dataset: A-C $=0.4777, \mathrm{~A}-\mathrm{G}=0.6338, \mathrm{~A}-\mathrm{T}=0.0968$, 
$\mathrm{C}-\mathrm{G}=0.6238, \mathrm{C}-\mathrm{T}=1.1010, \mathrm{G}-\mathrm{T}=1.0000$ (Proportion of invariable sites $[\mathrm{I}]=0.5280$; Gamma distribution shape parameter $=0.9553$; Model selected: GTR $+\mathrm{I}+\mathrm{G}$ ); for ITS + rpS4-trnT-trnL combined dataset: A-C $=0.5621$, $\mathrm{A}-\mathrm{G}=1.2123, \mathrm{~A}-\mathrm{T}=0.3214, \mathrm{C}-\mathrm{G}=0.3810, \mathrm{C}-\mathrm{T}=5.0583$, $\mathrm{G}-\mathrm{T}=1.0000$ (Proportion of invariable sites $[\mathrm{I}]=0.5978$; Gamma distribution shape parameter $=0.5788$; Model selected: GTR + I + G) and Rates = gamma.

The Markov Chain Monte Carlo process was set so that four chains ran simultaneously for 2,000,000 generations, with trees being sampled every 100 generations for a total of 20,000 trees in the initial sample. As "stationarity" was achieved by the 3,000th tree, the first 3,000 trees were discarded and the posterior probability of the phylogeny and its branches was determined from the remaining 17,000 trees. Internodes with posterior probabilities $\geq 95 \%$ were considered to be well-supported.

Parsimony and Maximum Likelihood. - For the combined dataset (138 taxa), a parsimony analysis and a maximum likelihood analysis (ML) were performed with PAUP Version 4.0b10 (Swofford, 2002). For the parsimony analysis, due to the impracticability of performing standard analyses on our large dataset, we used the PAUPRat approach (Nixon, 1999; Sikes \& Lewis, 2001), a tool for implementing Parsimony Ratchet searches using PAUP. Rather than performing many thorough and independent heuristic searches, the Ratchet performs what amounts to a single long search comprising a series of short heuristic searches. We have performed 200 iterations with TBR branch swapping. All most parsimonious trees (MPT) were saved and PAUP was used for computing a strict consensus tree. For the strict consensus tree, consistency index (CI), retention index (RI) and homoplasy index (HI), all excluding uninformative characters, have been calculated.

A bootstrap analysis (BS) (Felsenstein, 1985) was done to obtain support estimates for the nodes in the strict consensus tree. The analysis was performed using the approach by Lidén \& al. (1997) using 1,000 replicates, random taxon addition with 10 replicates per replicate and no branch swapping.

For the ML analysis, we started with a tree generated by Neighbor Joining (NJ) and used the SYM + G (Zharkikh, 1994) evolutionary model which best fits the data according to MrModeltest 2.2 (Nylander, 2004). Because of the large size of our dataset we accelerated the analysis using a ratchet approach according to the following parameters suggested by Morrison (2007): SPR branch swapping, re-weight $25 \%$ of the characters, 10 iterations of re-weighting, ApproxLim no more than $2 \%$ which indicates that approximate scores within $2 \%$ of the optimum will be evaluated fully, and MULTREES inactivated.

Partition homogeneity test. - In order to investigate whether the ITS and rpS4-trnT-trnL datasets can be combined, a partition homogeneity test (Farris \& al., 1994;

implemented in PAUP* 4.0b10; Swofford, 2002) with 10 homogeneity replicates, 10 random addition sequences, tree-bisection-reconnection (TBR) branch swapping on best only and MULTREES on was performed. In order to explore the congruency of the two datasets further, the congruency of individual clades with $\geq 0.95 \mathrm{PP}$ found in the ITS and rpS4-trnT-trnL datasets was compared.

Molecular clock analysis. - A likelihood ratio test (Felsenstein, 1988) was performed on the tree resulting from the ML analysis (1,000 random addition sequence, TBR and MULTREES on, after Zhang \& al., 2007) of the ITS dataset. Modeltest 3.5 (Posada \& Crandall, 1998) was used to perform the likelihood ratio test comparing the log-likelihood scores of the tree with and without enforcing a molecular clock. Degrees of freedom were equal to $s-2$ where s equals the number of taxa in the analysis. A significant difference at the 0.01 level between two scores was observed. Following this, PAUP* 4.0b10 (Swofford, 2002) was used to calculate genetic distances among taxa. After eliminating all taxa with large genetic distances to Saussurea elegans, a clock-like tree with 112 taxa was obtained.

As we could not identify appropriate fossils of the study group to calibrate our molecular clock tree (but see below), published ITS substitution rates were used for calibration. According to Kay \& al. (2006), ITS substitution rates in herbaceous angiosperms vary between $1.72 \times 10^{-9}$ to $8.34 \times 10^{-9}$ (mean $\left.=4.13 \times 10^{-9}\right)$ substitutions/site/year. The approximate age of seven nodes of our molecular clock tree was determined using the above three rates.

\section{RESULTS}

Partition homogeneity test. - No significant incongruence ( $P=0.01$ ) between the two datasets was detected in the partition homogeneity test.

The clades with $\geq 0.95$ PP found in the ITS and $r p S 4$ trnT-trnL trees, respectively, in the majority of cases are not congruent among the trees (Figs. 2, 3; Appendix 2). Thus, of the seven clades (or nested subclades) found in the rpS4-trnT-trnL tree, only one (clade 1) is found in the ITS tree (clade 8, containing one additional species). The remaining six clades are not present in the ITS tree, and the constituent species are separated by at least one branch with $\geq 0.95$ PP. Equally, of the 28 clades found in the ITS tree, only three clades (clades 2, 9, 17) plus two species of one clade (clade 8) are recovered as clades with $\geq 0.95$ PP by the rpS4-trnT-trnL data. The third species of clade 8 of the ITS tree, C. gmelinii C. Winkl., is separated from the other two species by several branches in the rpS4$\operatorname{trnT}$-trnL tree although none of these has $\geq 0.95 \mathrm{PP}$. The remaining 24 ITS clades are not present in the rpS4-trnT$\operatorname{trnL}$ tree, and in 13 of these clades the species constituting 
the ITS clades are separated by at least one branch with $\geq 0.95 \mathrm{PP}$ in the rpS4-trnT-trnL topology. Considering the results of this clade-by-clade comparison, the finding of congruency between the two datasets by the partition homogeneity test is somewhat surprising.

Phylogenetic analysis. - The numerical results of the analyses of the ITS, rpS4-trnT-trnL and combined ITS + rpS4-trnT-trnL datasets are given in Table 1. The individual datasets were analyzed with Bayesian inference (BI), and the combined dataset with Maximum Parsimony (MP), Bayesian inference (BI) and Maximum Likelihood
(ML). The results of the analyses of all three datasets with BI are shown in Figs. 2-4, the result of the MP analysis is partially shown in Fig. 6 (only the Arctioid clade) and the results of the ML analysis of the combined dataset are not shown.

All analyses confirmed the monophyly of the Arctium-Cousinia complex. Support for this was strong in the $\mathrm{MP}$ and $\mathrm{BI}$ analyses $(\mathrm{BS}=89 \%, \mathrm{PP}=1.00)$. Except for the BI analysis of rpS4-trnT-trnL alone, all analyses also show a clear subdivision of the complex into three groups: an Arctioid clade moderately supported by BS but well

Table 1. Numerical results of the analyses of the ITS, rpS4-trnT-trnL and combined ITS + rpS4-trnT-trnL datasets.

\begin{tabular}{|c|c|c|c|c|c|c|c|c|c|c|c|c|}
\hline \multirow{3}{*}{ Total characters } & \multicolumn{4}{|c|}{ ITS } & \multicolumn{4}{|c|}{ rpS4-trnT-trnL } & \multicolumn{4}{|c|}{ Combined ITS + rpS4-trnT-trnL } \\
\hline & \multicolumn{4}{|c|}{489} & \multicolumn{4}{|c|}{1,109} & \multicolumn{4}{|c|}{1,598} \\
\hline & tree & -out. & Cous. & Arct. & tree & -out. & Cous. & Arct. & tree & -out. & Cous. & Arct. \\
\hline Inf. & 172 & 143 & 143 & 51 & 28 & 21 & 21 & 7 & 216 & 171 & 140 & 58 \\
\hline Tree length & 799 & 680 & 546 & 85 & 78 & 55 & 38 & 11 & 980 & 836 & 679 & 105 \\
\hline CI & 0.308 & 0.290 & 0.300 & 0.647 & 0.603 & 0.545 & 0.579 & 0.636 & 0.299 & 0.272 & 0.274 & 0.590 \\
\hline RI & 0.721 & 0.728 & 0.624 & 0.886 & 0.922 & 0.931 & 0.909 & 0.810 & 0.711 & 0.715 & 0.586 & 0.849 \\
\hline HI & 0.692 & 0.710 & 0.700 & 0.353 & 0.397 & 0.455 & 0.421 & 0.364 & 0.701 & 0.728 & 0.726 & 0.410 \\
\hline
\end{tabular}

Tree length, CI, RI and HI were calculated for entire trees, for trees without outgroups and for the Arctioid and the Cousinioid clades. Abbreviations: Arct., Arctioid clade; CI, consistency index; Cous., Cousinioid clade; HI, homoplasy index; Inf., phylogenetically informative characters; -out., outgroups excluded; RI, retention index; tree, the entire tree including outgroups.

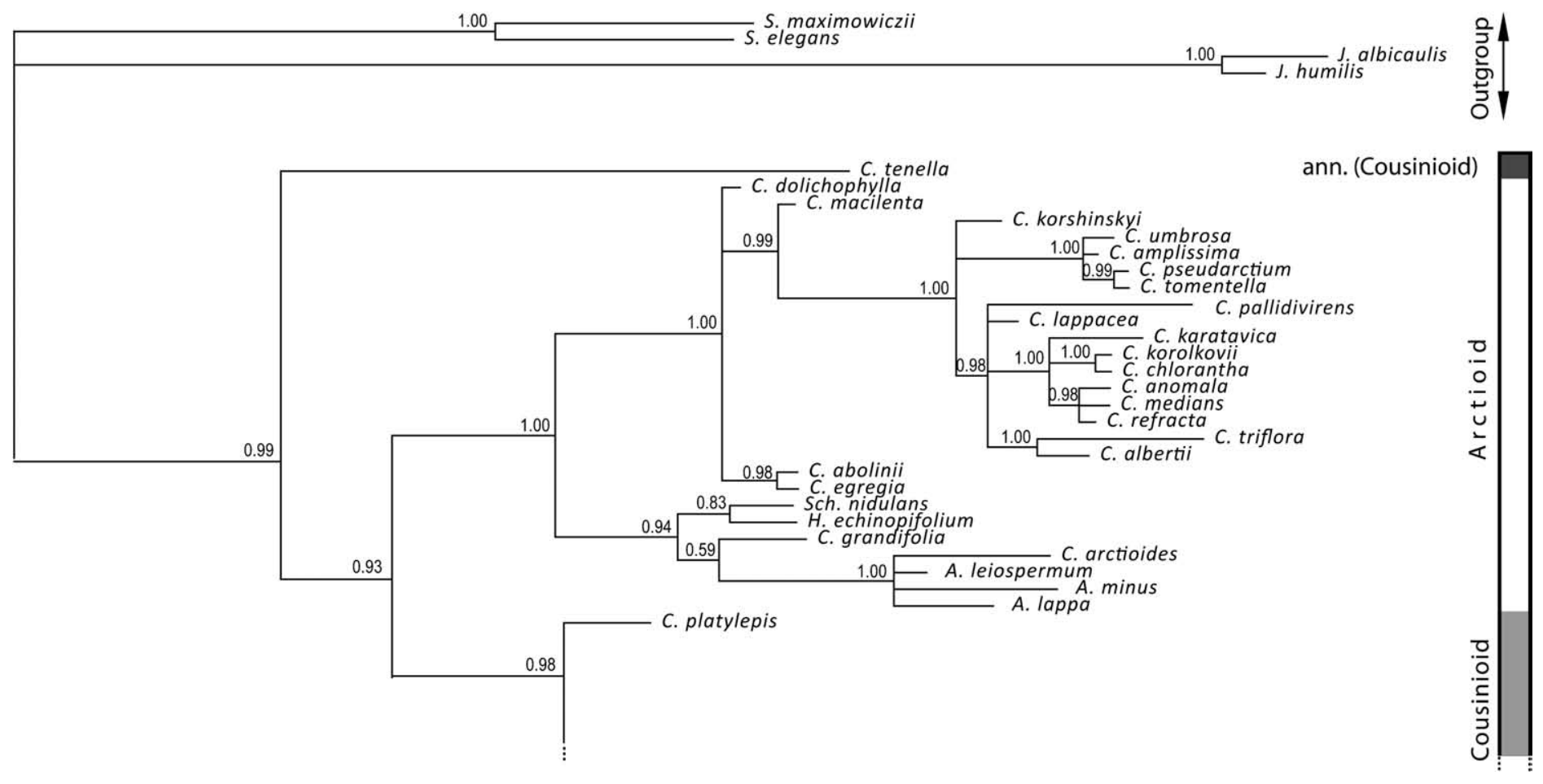

Fig. 2. 50\% majority-rule consensus tree obtained from the Bayesian analysis of the ITS dataset. Numbers on branches are posterior probabilities. ann. = annual species. Numbers at curly brackets indicate clades with $>0.95$ PP discussed in the text. 


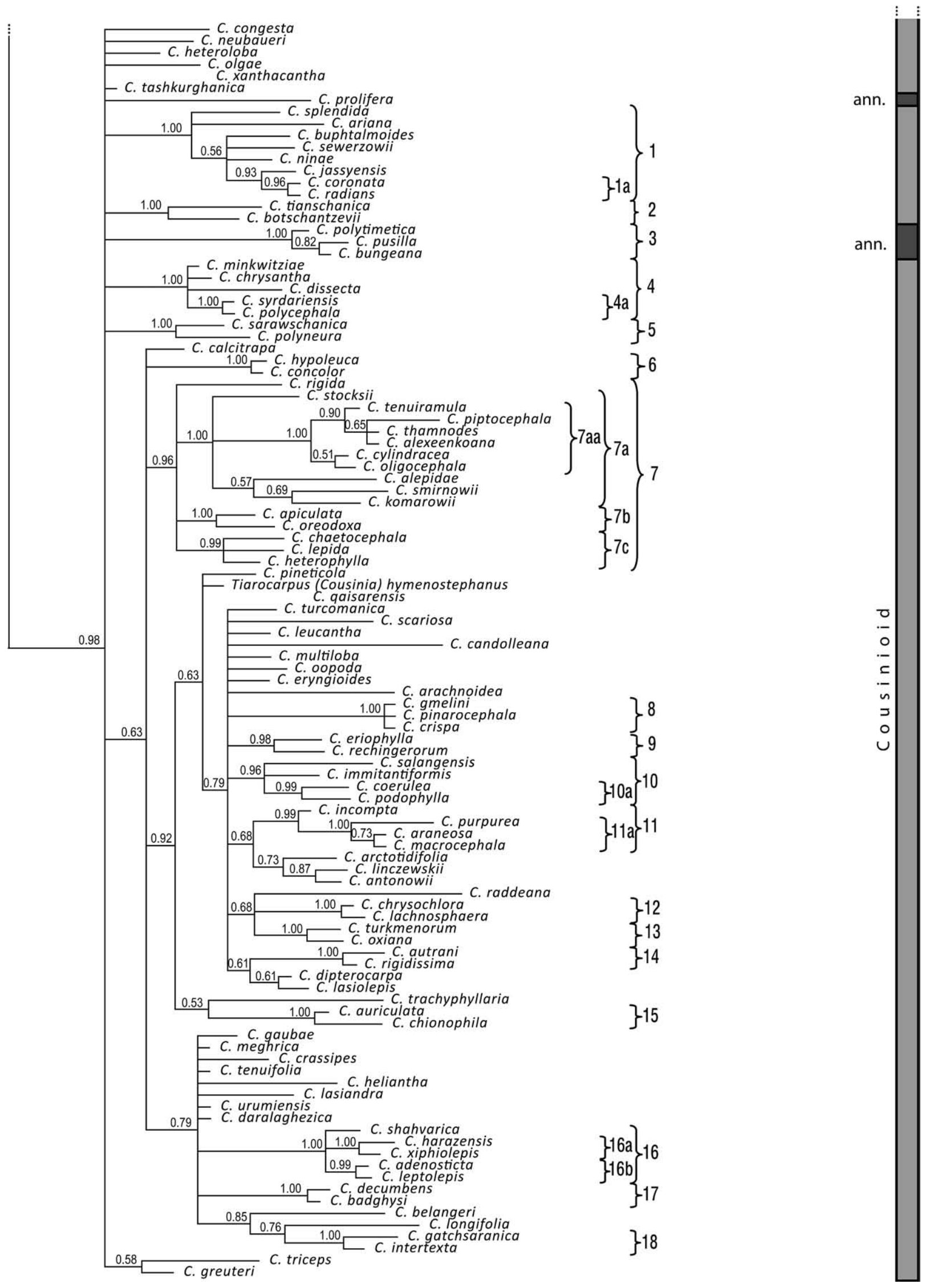


supported by PP $(\mathrm{BS}=72 \%$, PP $=1.00)$ which contains Arctium, Cousinia subgg. Cynaroides and Hypacanthodes, Hypacanthium and Schmalhausenia, a Cousinioid clade with BS $<50 \%$ but with strong Bayesian support $(\mathrm{PP}=1.00)$ which contains most species of Cousinia subg. Cousinia, and C. tenella Fisch. \& C.A. Mey. as sister to the above two clades (BS $=54 \%, \mathrm{PP}=0.89$ ). In the $\mathrm{BI}$ analysis of rpS4-trnT-trnL, C. tenella falls into the Arctioid clade with only low PP.

The Arctioid clade. - The description of the Arctioid clade is based on the tree obtained from the MP analysis of the combined dataset (Fig. 6). This tree is essentially congruent with the BI tree but better suited for character mapping. Within the Arctioid clade relationships among species are reasonably well resolved and this clade is subdivided into two subclades (Fig. 6). The first subclade, with moderate BS (80\%) but strong PP support (1.00) is formed by most species of Cousinia subgg. Cynaroides and Hypacanthodes. This subclade consists of an unresolved polytomy containing four species of subg. Hypacanthodes (C. egregia Juz., C. dolichophylla Kult.,
C. abolinii Kult. ex Tscherneva, C. macilenta Winkl.) in two lineages plus a well-supported clade (BS $=90 \%$, PP $=1.00$ ) formed by most of species of subg. Cynaroides which in turn fall into two unsupported subgroups. The second subclade also has good support (BS = 81\%, PP $=1.00$ ) and is formed by Arctium together with C. arctioides Schrenk of subg. Cynaroides (BS $=92 \%, \mathrm{PP}=$ 1.00), Cousinia grandifolia Kult. of subg. Hypacanthodes, Schmalhausenia and Hypacanthium. Relationships in the Arctioid clade as described above are essentially similar in the BI analyses of the ITS and combined dataset and in the ML analysis of the combined dataset.

The Cousinioid clade. - Relationships among species in the Cousinioid clade are essentially unresolved in the MP analysis of the combined dataset. Resolution is better in the BI analyses of the ITS and combined datasets and will be further discussed below (see Discussion).

Molecular clock analysis. - The results of our molecular clock analysis are shown in Table 2 and Fig. 5. Mai (2001) reported fossil Arctium achenes from a German Miocene locality. The age of this fossil can be dated

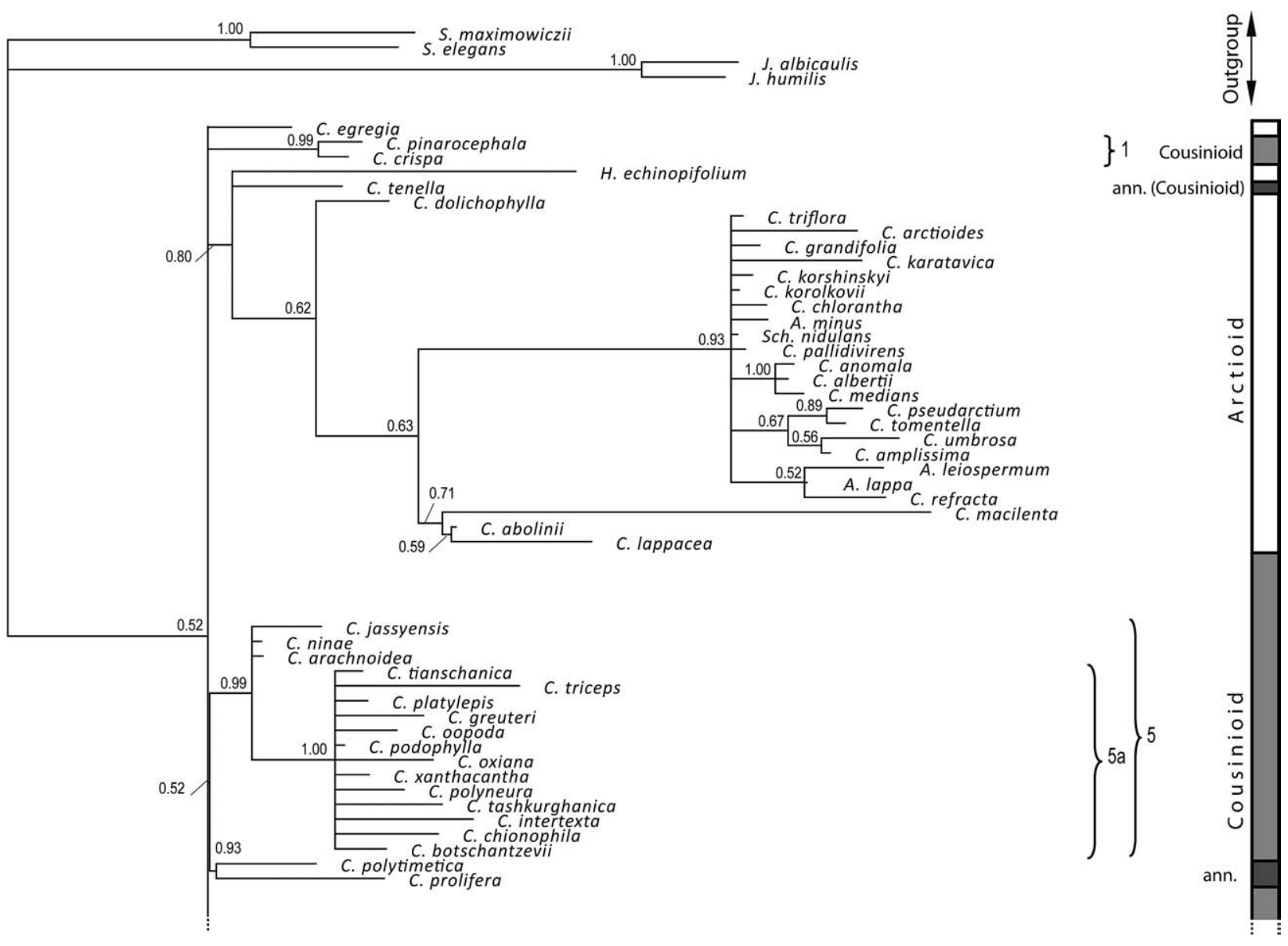

Fig. 3. $50 \%$ majority-rule consensus tree obtained from the Bayesian analysis of the rpS4-trnT-trnL dataset. Numbers on branches are posterior probabilities. ann. = annual species. Numbers at curly brackets indicate clades with $>0.95$ PP discussed in the text. 
to 7-9 mya (V. Wähnert, pers. comm.). Considering that the achenes of Arctium can not be reliably distinguished from those of the other genera of the Arctium-Cousinia complex, this fossil essentially is compatible with the ages calculated for the complex with all three ITS substitution rates. When considering the occurrence of this achene in Germany, and assuming that the geographical distribution of the complex in the past was similar to its distribution today, with Arctium being the only genus occurring in
Europe, the fossil probably is best assigned to Arctium. This would imply that of the three ITS substitution rates used for the calibration of the molecular clock, the mean rate fits best. With this rate, the clade containing Arctium (node F in Fig. 5) was dated to ca. 6.3 my (crown group age). Based on the above considerations, we will refer mainly to ages obtained when using the mean ITS substitution rate in the following discussion, and these ages are also indicated in Fig. 5.
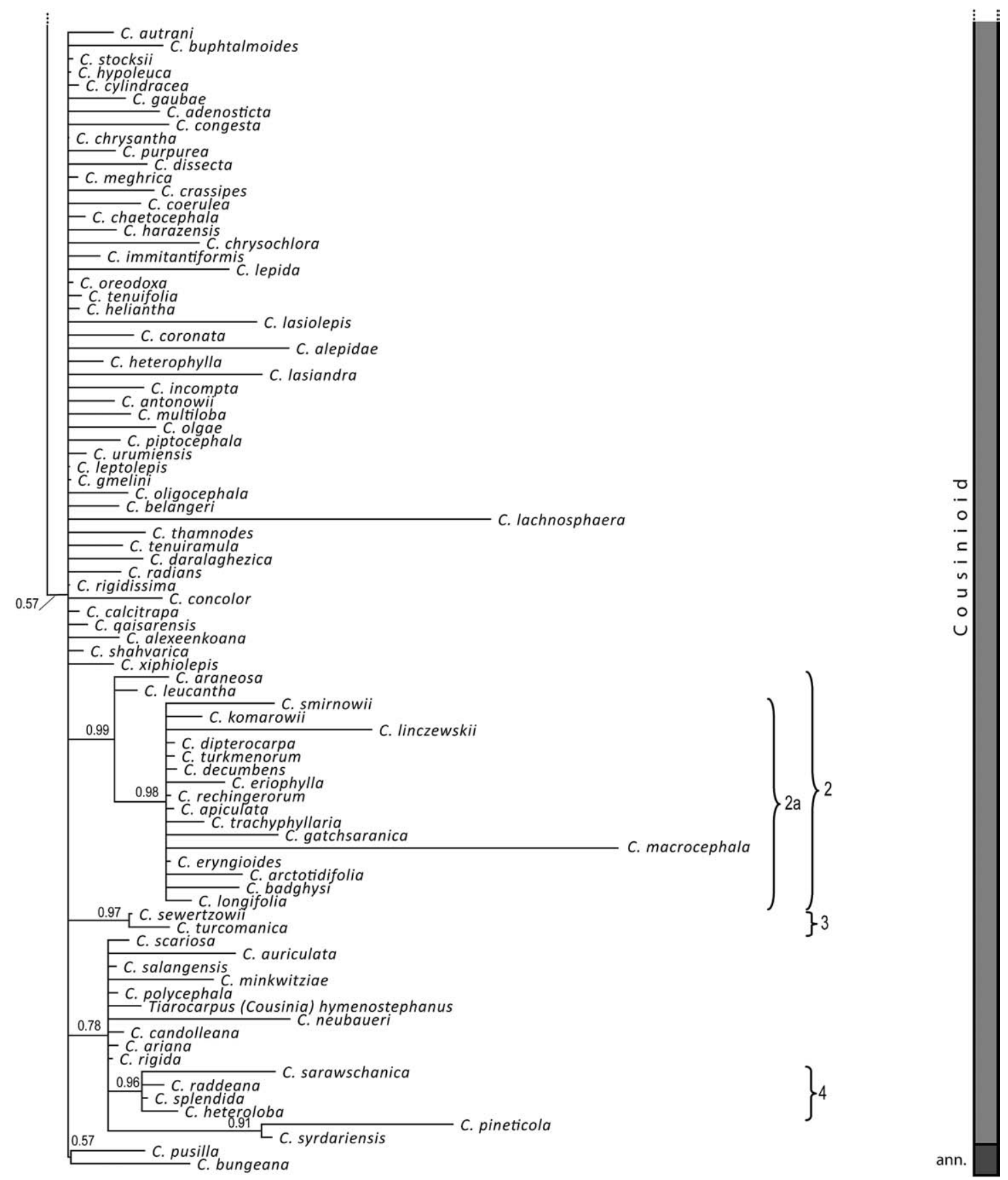


\section{DISCUSSION}

The Arctium-Cousinia complex. - As already found by previous authors (Susanna \& al., 2003a; Susanna \& Garcia-Jacas, 2007), the Arctium-Cousinia complex clearly is monophyletic with good support in the MP and $\mathrm{BI}$ analyses $(\mathrm{BS}=89 \%, \mathrm{PP}=1.00)$. In all analyses except the $\mathrm{BI}$ analysis of rpS4-trnT-trnL a division into three groups, the Arctioid clade, the Cousinioid clade and Cousinia tenella was found.

When comparing the Arctioid and Cousinioid clades, two major differences can be observed. First, whereas intraclade relationships are reasonably well-resolved in the Arctioid clade, very little resolution was obtained in the Cousinioid clade. Considering that the two clades are sister to each other, and that crown group diversification of the two clades started at approximately the same time (mean rate: Arctioid clade: ca. 9.7 mya, Cousinioid clade: ca. 8.7 mya; Table 2), differential age of the two groups can not
Table 2. Absolute ages in million years (my) obtained from the molecular clock analysis.

\begin{tabular}{lccc}
\hline & Rate $\mathbf{1}(\mathbf{m y})$ & Mean rate $(\mathbf{m y})$ & Rate $\mathbf{2}(\mathbf{m y})$ \\
\hline Node A & 45.930 & 19.128 & 9.472 \\
Node B & 35.465 & 14.770 & 7.314 \\
Node C & 23.256 & 9.685 & 4.796 \\
Node D & 20.930 & 8.717 & 4.317 \\
Node E & 16.860 & 7.022 & 3.477 \\
Node F & 15.116 & 6.295 & 3.118 \\
Node G & 10.465 & 4.358 & 2.158 \\
\hline
\end{tabular}

Rate $1=1.72 \times 10^{-9}$ substitutions/site/year; mean rate $=4.13 \times$ $10^{-9}$ substitutions/site/year; rate $2=8.34 \times 10^{-9}$ substitutions/ site/year (Kay \& al., 2006).

be advocated as explanation for the difference in phylogenetic resolution. Instead, we believe that the striking difference in species number is responsible for the difference

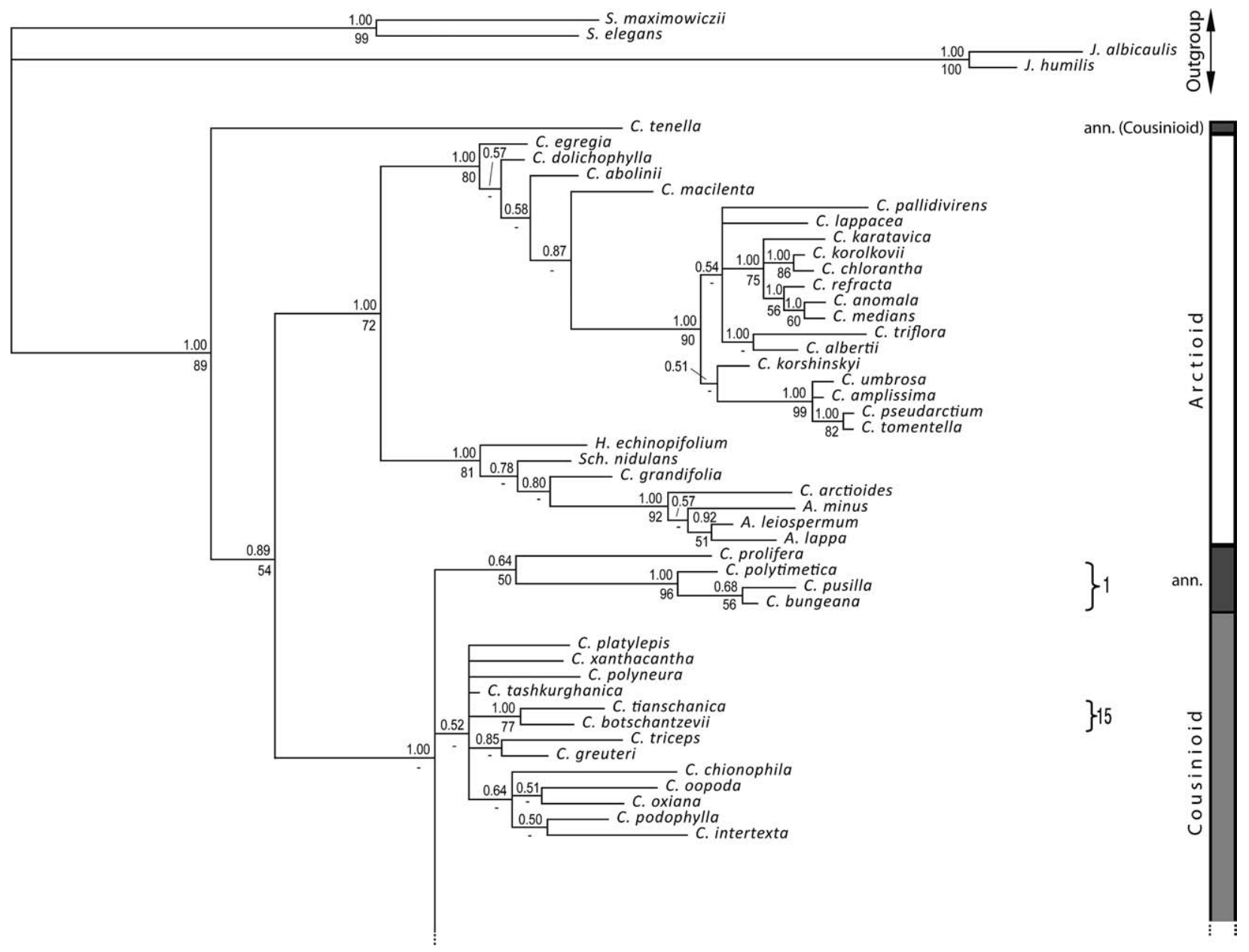

Fig. 4. 50\% majority-rule consensus tree obtained from the Bayesian analysis of the combined ITS and rpS4-trnT-trnL dataset. Numbers above branches are posterior probabilities and numbers below branches are bootstrap percentages. ann. = annual species. Numbers at curly brackets indicate clades with $>0.95$ PP discussed in the text. 
in phylogenetic resolution. If the Cousinioid clade were to be reduced to a random sample of species equal in number to that of the Arctioid clade, phylogenetic resolution probably would be greatly improved. Indeed, this prediction is to some extent confirmed by the data of Susanna \& al. (2003a), who obtained some phylogenetic structure among the 21 species of the Cousinioid clade included in their analysis.

Second, presumably plesiomorphic and apomorphic characters are distributed unevenly across the two clades.

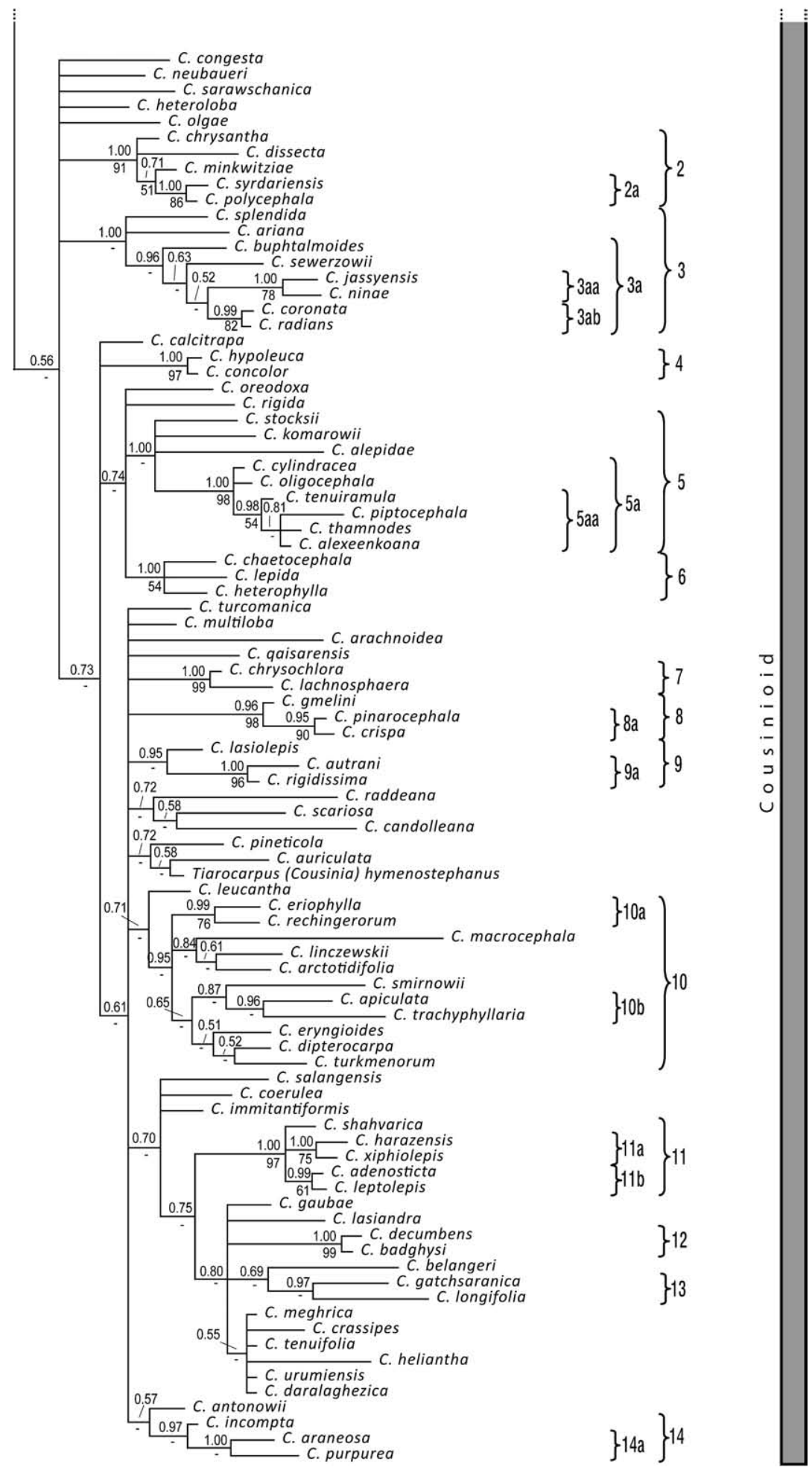




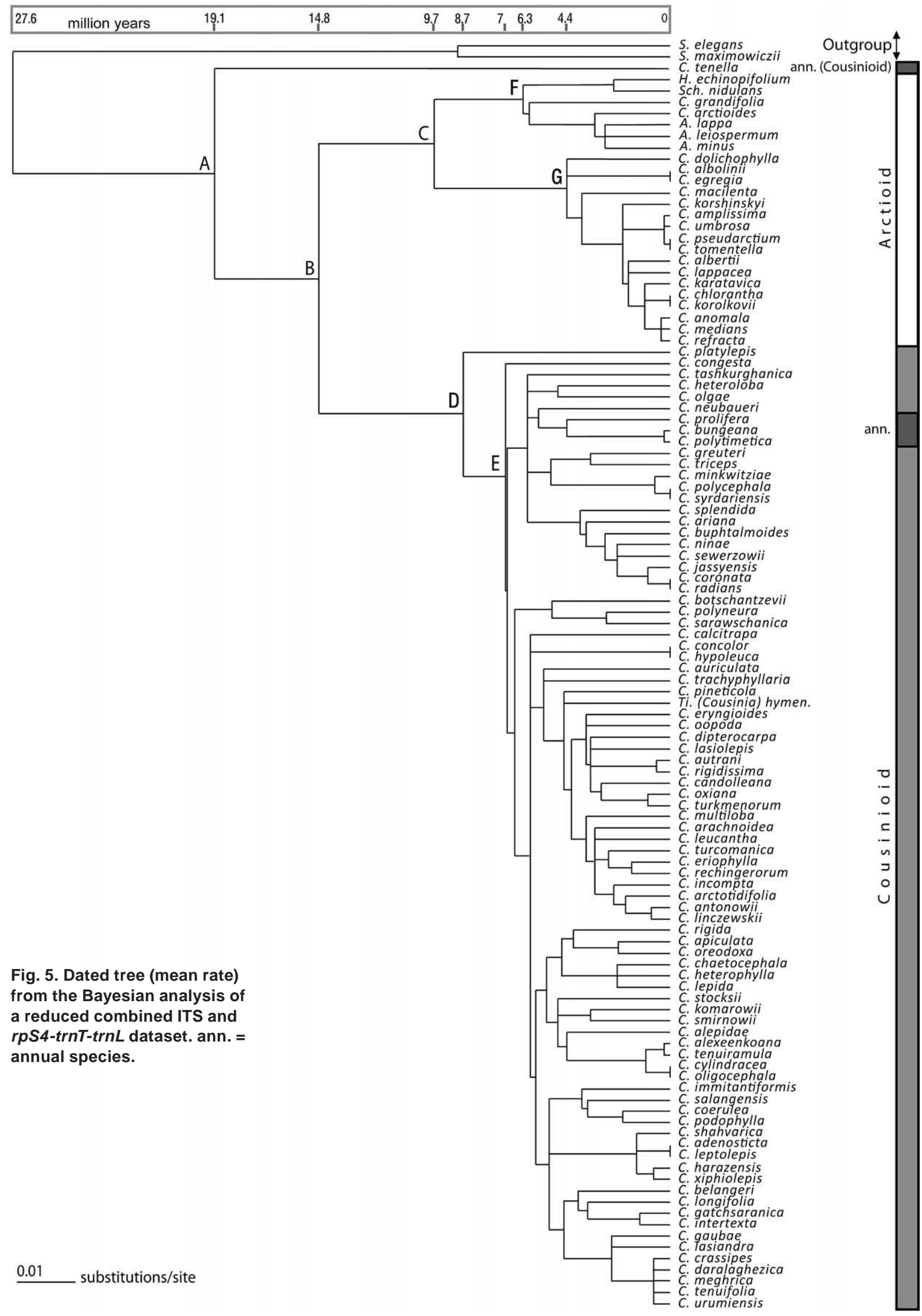


Whereas the spiny pollen (and possibly also long stigmata) of the Arctioid clade can also be found in Jurinea and Saussurea (Punt \& Hoen, 2009) as closest relatives of the Arctium-Cousinia complex, the short stigmata and smooth pollen of the Cousinioid clade appear to be apomorphic. In other groups of Cardueae, pollen morphology is associated with the pollen presentation mechanism. In Centaureinae (Garcia-Jacas \& al., 2001; Vilatersana \& al., 2001), basal groups have spiny pollen and long, usually dry stigmata and lack a touch-sensitive pollen presentation mechanism. More derived groups have very short, sticky stigmata and smooth pollen, and this is associated with touch-sensitive pollen presentation. We hypothesize that a similar transition of characters has taken place in the Arctium-Cousinia complex. As regards chromosome numbers, the Arctioid clade is rather stable with a base chromosome number of $x=18$. Much in contrast to this, considerable descending dysploidy $(x=9,10,11,12,13)$ is found in the Cousinioid clade. Of the closest relatives of the complex, Jurinea has a base chromosome number of $x=17$ and Saussurea of $x$ $=13$. In general, basal Carduinae have higher chromosome numbers. The distribution of chromosome numbers in comparison of the Arctioid and Cousinioid clades again is paralleled in subtribe Centaureinae where an evolutionary trend from high to low chromosome numbers has been reported (Garcia-Jacas \& al., 2001). Finally, it could be argued that the Arctioid and Cousinioid clades differ in habitat diversity. Whereas species of the Arctioid clade, with the obvious exception of the widespread colonizers mainly of Arctium, are more or less confined to high mountain habitats, species of the Cousinioid clade have diversified and grow in widely different habitats including semidesert areas, open hilly areas, alpine ecosystems, high altitude areas transitional between humid and semiarid ecosystems, oak forest floors and rarely in lowlands. Possibly the differential species richness of the Arctioid and Cousinioid clades on the one hand and the unequal distribution of plesiomorphic vs. apomorphic characters among the two clades are not only correlated but causally linked. However, whether transition to apomorphic characters in the Cousinioid clade is cause or effect of its higher species number can not be easily decided with the data available.

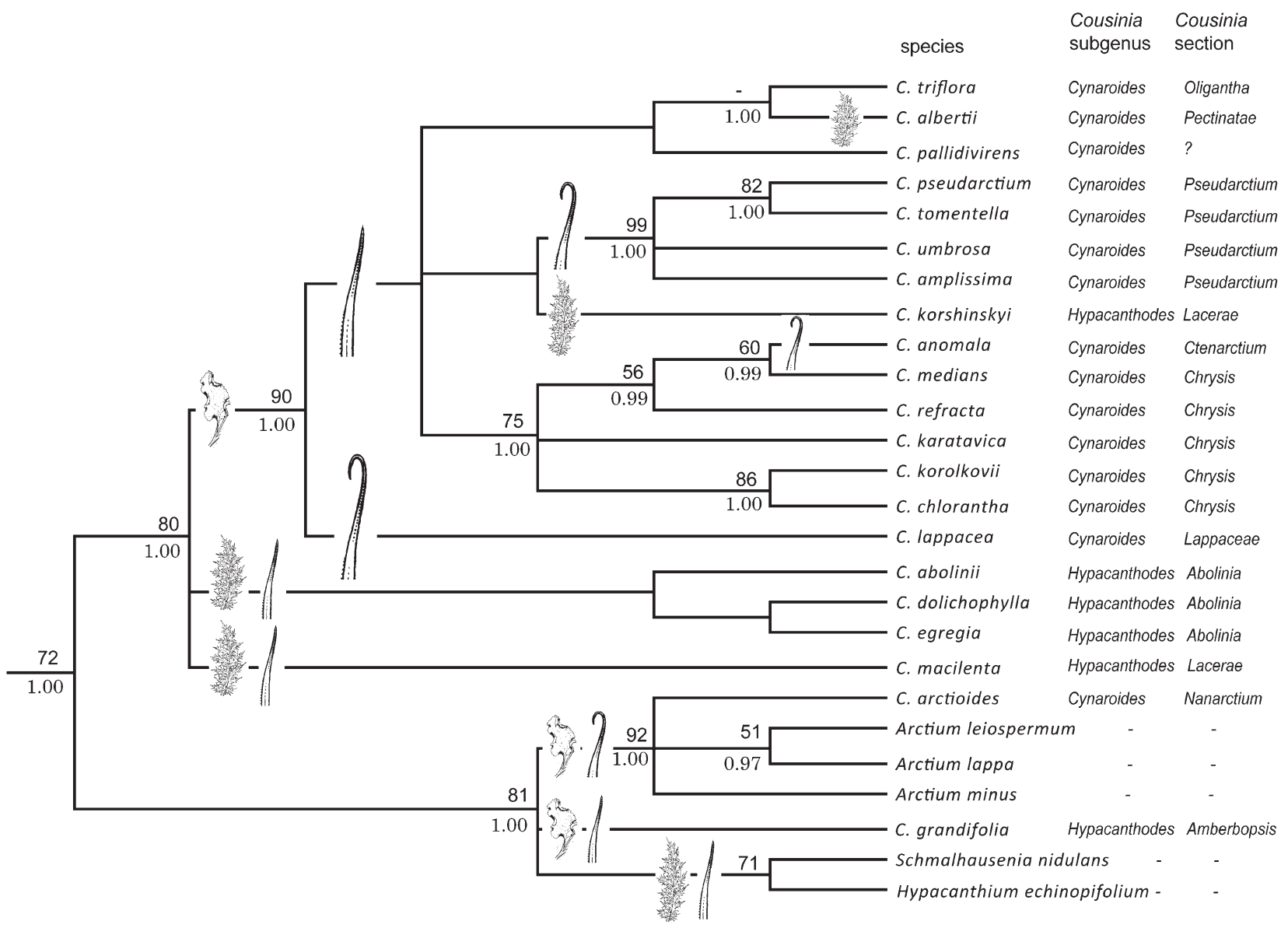

Fig. 6. Distribution of leaf and involucral bract morphology among species of the Arctioid clade mapped on an MP tree of the combined ITS and rpS4-trnT-trnL dataset. 
The Arctioid clade. - As described in the introduction, the Arctioid clade can not be characterized morphologically beyond pollen and style morphology (neither chromosome number). Part of it (Arctium and four species of Cousinia subg. Cynaroides) have unarmed, large cordate leaves and involucral bracts ending in a recurved hook. Of the remainder of subg. Cynaroides, six species have leaves which are not cordate but involucral bracts ending in a hooked spine, and twelve species have involucral bracts ending in a straight spine. The distribution of these two characters precludes the morphological definition of a monophyletic Arctium. In subg. Hypacanthodes no species has either cordate leaves or hooked involucral bracts. The distribution of spiny leaves also runs across established generic and subgeneric boundaries. All species of Arctium and almost all species of Cousinia subg. Cynaroides have unarmed leaves, and only C. alberti Regel \& Schmalh. and C. horrescens Juz. are spiny. In contrast to this, Schmalhausenia, Hypacanthium and Cousinia subg. Hypacanthodes (except C. grandifolia) have strongly spiny leaves.

A logical solution to the above character distribution would be to establish a broadly redefined Schmalhausenia including Hypacanthium and the spiny species of Cousinia subg. Hypacanthodes, and a broadly redefined Arctium including subg. Cynaroides and the unarmed C. grandifolia from Cousinia subg. Hypacanthodes. However, this solution clearly is not compatible with molecular evidence presented here. In fact, the tree topology (Fig. 6) suggests the recognition of two to four groups: (1) Schmalhausenia plus Hypacanthium, (2) Cousinia grandifolia, (3) Arctium incl. Cousinia arctioides and (4) the remaining species of Cousinia subgg. Cynaroides and Hypacanthodes. However, this solution is not compatible with morphological evidence. In conclusion, our declared aim to revise generic limits in the Arctioid clade on the basis of a larger taxon sample could not be achieved because of the molecular placement and morphology of the species of Cousinia subgg. Cynaroides and Hypacanthodes. When considering the distribution of leaf and involucral bract morphology across the phylogeny of the entire complex (Fig. 6), it is obvious that either cordate and unarmed or spiny leaves and apically hooked or straight involucral bracts - these two characters are not always correlated-evolved several times in parallel. In view of the uncertainties in our phylogeny we did not try to formally optimize the evolution of these characters.

Interestingly, the only colonizing species of the Arctium-Cousinia group, i.e., most species of Arctium, have capitula with hooked involucral bracts. Such capitula are dispersed epizoochorously and may be direct cause of the colonizing success of the genus. However, some species with hooked involucral bracts are geographically limited to the Tien-Shan. It seems possible that the biennial habit of Arctium - most other species of the Arctioid clade are perennial—contributed to this colonizing success as already suspected by Duistermaat (1996).

The sectional classification of Cousinia subg. Cynaroides and subg. Hypacanthodes is only partly supported by our results, and neither subgenus is monophyletic as presently circumscribed (Fig. 6). One species of subg. Cynaroides, C. arctioides, is placed within the Arctium clade with good parsimony and Bayesian support (BS = $92 \%, \mathrm{PP}=1.00$ ). This position is fully congruent with morphology as C. arctioides has unarmed leaves as well as involucral bracts ending in a recurved hook. We propose to follow the taxonomical criterion of Kuntze (1891) and Duistermaat (1996) which consider this species as Arctium arctioides (Schrenk) Kuntze.

Apart from this, our phylogeny is largely congruent with the current sectional classification of subg. Cynaroides. The species of sect. Chrysis (C. medians Juz. through C. chlorantha) form a clade with low BS (75\%) but high PP (1.0) support. However, this clade also includes C. anomala Franch. of sect. Ctenarctium. This grouping is not supported by morphological characters as $C$. anomala has involucral bracts ending in a hook and oblong-lanceolate leaves. Section Pseudarctium (C. pseudarctium Bornm. through C. amplissima Boiss.) is a strongly supported clade $(\mathrm{BS}=99 \%, \mathrm{PP}=1.00)$ containing species with involucral bracts with hooked spines and large, soft and slightly pubescent leaves. Sections Oligantha and Pectinatae group together with BS $<50 \%$ but strong BI support $(\mathrm{PP}=1.00)$. This grouping is not supported by any morphological characters and may result from the poor representation of sect. Pectinatae in our sample.

Two species of subg. Hypacanthodes were resolved in unexpected position. Thus, C. korshinskyi Winkl. of sect. Lacerae is part of the subg. Cynaroides clade discussed above and separated from the other species of sect. Lacerae included in the analysis (C. macilenta). This grouping is incongruent with morphology because $C$. korshinskyi is more similar to the rest of subg. Hypacanthodes than to subg. Cynaroides. Cousinia grandifolia is part of the clade containing Arctium, Schmalhausenia and Hypacanthium. In this case, this placement is well correlated with morphology. Cousinia grandifolia shares the possession of large, unarmed, oblong-ovate leaves with Arctium, and involucral bracts ending in a spine without hook with Schmalhausenia and Hypacanthium. With these characters $C$. grandifolia is somewhat intermediate between Arctium on the one hand and Schmalhausenia and Hypacanthium on the other hand.

The sectional classification of subg. Hypacanthodes is not confirmed by our data. Although the species of sect. Abolinia form a clade which is homogeneous morphologically, this clade has no statistical support. Cousinia macilenta and C. korshinskyi of sect. Lacerae are placed in two different and strongly supported clades (see above). 
They had been placed in separate series of sect. Lacerae, Macilentae and Pterolepideae, by Tscherneva (1962) and differ in pubescence, height and branching of the stem, leaf size, capitulum pubescence, shape and texture of the involucral bracts and achene ornamentation.

The Cousinioid clade. - As evident from our Bayesian analyses of the ITS, rpS4-trnT-trnL and combined datasets (Figs. 2-4), and also from the MP and ML analyses of the combined dataset (not shown), very little phylogenetic resolution can be obtained within Cousinia subg. Cousinia. Although a varying number of mostly small species groups with high support is recognizable in the different datasets, relationships among species groups are essentially unresolved.

In the following discussion, we first will explore in detail the phylogenetic information contents of our data. This we will do by examining whether clades with $\geq 0.95$ PP are plausible in terms of traditional taxonomic assignment (as a proxy for morphological similarity) and/or geographical distribution by growing in the same general area. For this purpose, the following eight major centres of species diversity were defined (Fig. 1): Anatolian mountains, Zagros mountains, Elburz mountains, Kopet Dagh and mountains to the south, West Hindu Kush (C \& W Afghanistan), East Hindu Kush (NE Afghanistan), PamirAlay and Tien-Shan (Rechinger, 1986; Knapp, 1987). Second, we will investigate possible causes for the very limited amount of phylogenetic resolution obtained.

Phylogenetic information in the rpS4-trnT-trnL, ITS and combined datasets. - In the rpS4-trnT-trnL dataset, seven clades (or nested subclades) with $\geq 0.95 \mathrm{PP}$ were obtained (Appendix 2). Of these, clades 3 and 4 are not plausible in terms of traditional taxonomic assignment or geographical distribution. Clade 1 is plausible in both terms, and clades $2-2 \mathrm{a}$ and $5-5 \mathrm{a}$, with few exceptions (2-2a: C. araneosa DC., C. macrocephala C.A. Mey., C. gatchsaranica Mehregan, Assadi \& Attar; 5-5a: C. oxiana Tscherneva, C. intertexta Freyn \& Sint.), contain species from the Kopet Dagh area (S Turkmenistan, NE \& E Iran and NW Afghanistan) and Central Asia, respectively, but of different sections of Cousinia subg. Cousinia. In the ITS dataset, 28 clades (or nested subclades) with $\geq 0.95$ PP were obtained (Appendix 2). Of these, 16 are plausible both in terms of taxonomic assignment and geographical distribution, 2 are plausible in terms of taxonomic assignment only, 4 are plausible in terms of geographical distribution only, and the remaining 6 clades are not plausible in either terms. In the combined dataset, 28 clades (or nested subclades) with $\geq 0.95 \mathrm{PP}$ were obtained (Appendix 2). Of these, 13 are plausible both in terms of taxonomic assignment and geographical distribution, 4 are is plausible in terms of taxonomic assignment only, 4 in terms of geographical distribution only, and the remaining 7 clades are not plausible in either terms.
To summarize the above considerations, our datasets do appear to contain some plausible phylogenetic information mainly in their distal branches. When considering terms of clade plausibility, it also appears that geographical distribution is a more reliable criterion for recognizing phylogenetic relatedness than traditional taxonomic assignment as also found in other studies (e.g., GonzálezAlbaladejo \& al., 2005).

Most interestingly, and in support of the above conclusion, the annual species (except C. pygmaea C. Winkl.which does not appear in the trees shown-and C. tenella which groups outside Cousinia subg. Cousinia in all our analyses, for discussion see below) group in one clade in the majority of our analyses. In the ITS dataset (Fig. 2), C. bungeana, C. polytimetica and C. pusilla form one clade with $1.0 \mathrm{PP}$ which is part of a polytomy also containing C. prolifera. In the rpS4-trnT-trnL dataset (Fig. 3), C. prolifera Jaub. \& Spach and C. polytimetica Tscherneva form one clade (0.93 PP) widely separated (although by no branch with $\geq 0.95 \mathrm{PP}$ ) from C. pusilla C. Winkl. and C. bungeana Regel \& Schmalh. which are part of a large polytomy. In the Bayesian combined dataset (Fig. 4) these four annual species form one clade with $0.64 \mathrm{PP}$, of which C. bungeana, C. polytimetica and C. pusilla form a subclade with 1.0 PP. These four annual species are also recovered as a monophyletic group in the MP analysis of the combined dataset (50\% BS; C. bungeana, C. polytimetica, C. pusilla: 96\% BS; not shown), and C. bungeana, C. polytimetica and C. pusilla are recovered in the ML analysis of the combined dataset (not shown). The monophyly of the annual species (except C. pygmaea and C. tenella) in the combined dataset even more than the above considerations implies that our ITS and rpS4-trnT-trnL sequence data do contain limited but valuable phylogenetic information.

Possible causes for lack of phylogenetic resolution in Cousinia subg. Cousinia. - The first obvious reason for the lack of phylogenetic resolution obtained in the analyses of the ITS, rpS4-trnT-trnL and combined datasets is the small number of characters available in relation to the number of taxa analysed. For the 106 species included of Cousinia subg. Cousinia, the rpS4-trnT-trnL dataset yielded 21, the ITS dataset 143 and the combined dataset 140 parsimony informative characters (Table 1). Although in theory the number of parsimony informative characters in the ITS and combined datasets would be sufficient to resolve a phylogeny of 106 species, they are not, because the characters show considerable homoplasy. Although the RI for the rpS4-trnT-trnL dataset is high (0.922), it is fairly low for the ITS (0.721) and combined datasets (0.711). The most likely reason for the lack of characters in Cousinia subg. Cousinia is its comparatively young age (Table 2, Fig. 5) in combination with its high species number. Thus, using the average substitution rate for ITS for herbaceous perennials (Kay \& al., 2006) as to some 
extend justified by the age of the fossil Arctium achene by Mai (2001; see above), a crown group age of ca. $8.7 \mathrm{my}$ (node D) was found for Cousinia subg. Cousinia, and its major diversification started only ca. 7 mya (node E).

Considering the existence of a large number of closely related and often sympatric species with no obvious mechanism of reproductive isolation in Cousinia subg. Cousinia, hybridization and hybrid speciation seems possible and clearly would confound the reconstruction of phylogeny (Nieto-Feliner \& al., 2001; Font \& al., 2002; Vriesendorp \& Bakker, 2005; Suárez-Santiago \& al., 2007). Based on the examination of literature reports of hybrids and intermediate forms and the morphological and molecular examination of some suspected hybrids, Mehregan \& Kadereit (in press) concluded that although hybridization does occur in Cousinia, it seems to be comparatively rare in the genus. Thus, only 26 hybrids and 12 intermediate forms in Cousinia subg. Cousinia have been published (Tscherneva 1962; Rechinger, 1972, 1979). These hybrids and intermediate forms involve ca. $11 \%$ of the currently recognized species of Cousinia subg. Cousinia. The two hybrids examined in detail (C. shahvarica $\times$ C. decumbens, $C$. eryngioides $\times C$. chrysochlora), confirmed by additivity of their ITS sequences, showed reduced pollen fertility. It is possible that hybridization is much more frequent but undetected because of lack of sufficiently detailed taxonomic knowledge and the existence of several morphologically very similar species. However, the complete absence of polyploid chromosome numbers in Cousinia subg. Cousinia among the 148 species analyzed (http://www-asteraceae.cla.kobe-u.ac.jp/search.html) implies that polyploid hybrid speciation played no role in the evolution of Cousinia subg. Cousinia. Nothing can be said about the evolutionary significance of homoploid hybrid speciation in this group.

In summary, there is little evidence that hybridization and/or hybrid speciation are important factors hindering the reconstruction of the phylogeny of Cousinia subg. Cousinia.

The phylogeny and evolution of Cousinia subg. Cousinia. - As evident from the above discussion, very little can be said about the phylogeny of Cousinia subg. Cousinia. Although a number of species groups can be recognized which may well represent monophyletic lineages as judged from their taxonomic assignment and/or geographical distribution, relationships among species groups are entirely unclear and no major subdivision of Cousinia subg. Cousinia is evident from our data. This is most likely the result of paucity of phylogenetic informative characters contained in our ITS and rpS4-trnT-trnL datasets in relation to species number. This in turn is the result of the comparatively young geological age of the group in combination with its species richness. Apart from the recovery of a number of probably monophyletic species groups, our data contain valuable information about the evolution of annuality, a very rare condition in Cousinia subg. Cousinia. It appears that annuality originated twice in Cousinia subg. Cousinia. The first lineage of annuals, comprising $C$. bungeana, C. polytimetica, C. pusilla and C. prolifera has been discussed above and is well-nested within Cousinia subg. Cousinia. The second lineage comprises $C$. tenella and C. pygmaea and will be discussed further below.

With its comparatively young age and high species number Cousinia subg. Cousinia represents a massive radiation which is quite unusual because it took place in a comparatively small geographical area. Based on the results of an ongoing taxonomic revision of part of Cousinia subg. Cousinia (sect. Cynaroideae; Mehregan \& Kadereit, 2008), mainly two conclusions can be drawn about the evolution of this group. First, it seems very likely that the number of species described (ca. 600) vastly overstates the number of existing species. Thus, our revision reduced the number of species in sect. Cynaroideae from 110 to 31. If reduction in species number by two-thirds eventually will also take place in other parts of Cousinia subg. Cousinia, it would still remain a large genus with about 200 species. Second, of the ca. 30 species recognized by Mehregan \& Kadereit (2008), only two are geographically widespread, namely C. calocephala Jaub. \& Spach and C. onopordioides Ledeb. The remaining species have rather narrow and, most importantly, allo- or parapatric geographical ranges where species boundaries are marked by prominent topographical barriers. This may imply that the predominant speciation process in Cousinia subg. Cousinia may be geographical speciation. Today, the group is found mainly (but not exclusively) in vegetation types classified as 'Kurdo-Zagrosian and other steppe-forest climaxes' by Zohary (1973). When this type of vegetation is considered essentially identical with 'Mediterranean to subMediterranean Artemisia-Ephedra-Juniperus-Compositae steppe of mountainous regions' as defined by Frenzel \& al. (1992), the reconstruction of vegetation during the last glacial maximum (20.000 to 18.000 years ago) by Frenzel \& al. (1992) suggests that the geographical range of Cousinia subg. Cousinia in the last glacial maximum was compressed in only the northern parts of its extant range. This in turn implies substantial changes in geographical distribution of species during the Quaternary. Considering the age of the crown group diversification of Cousinia subg. Cousinia (ca. 8.7 mya; Table 2) and the age of species which in most cases is older than the onset of the Quaternary (Fig. 5), the climatic oscillations of the Quaternary do not appear to have resulted in widespread extinction of the group. Whether these climatic oscillations instead were a stimulus for speciation (through changes in geographical distribution), as found for, e.g., Primula L. sect. Auricula and Epimedium L. (Kadereit \& al., 2004; Zhang \& al., 2007), we can not say without further analysis. 
Cousinia tenella. - In all our analyses except the BI analysis of the rpS4-trnT-trnL dataset alone, C. tenella is sister to the Arctioid and Cousinioid clades. Support for the sister group relationship between the Arctioid and Cousinioid clades increases (BS = 94\%, PP = 1.00; tree not shown) when $C$. tenella is removed from the data matrix.

Although only $C$. tenella was included in the datasets shown here, an enlarged ITS dataset of 216 species (not shown) shows $C$. pygmaea to be sister to C. tenella with $0.84 \mathrm{PP}$. Such relationship is plausible considering the great similarity between the two species which differ only in flower colour, relative length of corolla tube and limb and achene shape (Rechinger, 1972). The placement of $C$. tenella in most of our analyses might suggest segregation of C. tenella and C. pygmaea from Cousinia subg. Cousinia. On the basis of karyology, pollen type and stigma morphology, however, C. tenella (and probably C. pygmaea) clearly falls into the Cousinioid clade. Cousinia tenella has $2 n=26$ chromosomes according to Aryavand (1975) and Susanna \& al. (2003b), the Cousinioid pollen type and stigma morphology (Susanna, pers. comm.). The fact that this species is resolved as sister to the rest of the Arctium-Cousinia complex probably is due to its annuality, autogamy and probably increased mutation rate. There exist other examples for unexpected placements of annuals in tribe Cardueae. In Echinops L., annual species together with the annual Acantholepis Less. are sister to the rest of the genus (Garnatje, 2005); in Ptilostemon Cass., the only annual species, Ptilostemon stellatus (L.) Greuter, is sister to the rest of the genus (Vilatersana $\&$ al., in prep.); and in subtribe Centaureinae the annual Schischkinia Iljin and Stizolophus Cass. are successive sisters to the rest of the subtribe (Garcia-Jacas \& al., 2006). In all these cases, the position of annuals as sister to the remainder of their respective groups is not congruent with morphology. Several authors have pointed out that annual plants often have an elevated rate of molecular evolution compared with perennials, explained by generation time, population size, and speciation rate (Bousquet \& al., 1992; Laroche \& al., 1997; Andreasen \& Baldwin, 2001). If this indeed should be the explanation for the unexpected placement of $C$. tenella, it is interesting to observe that this problem does not appear to exist for the equally annual C. bungeana/C. polytimetica/C. pusilla/C. prolifera lineage which clearly falls into the Cousinioid clade as expected from morphology.

\section{ACKNOWLEDGEMENTS}

This work was supported by the Ministry of Education and Science, Spanish Government (project CGL 2004-04563C02-01/BOS and Ph.D. grant to S. López-Vinyallonga) and the Deutscher Akademischer Auslandsdienst (DAAD; Ph.D. grant to Iraj Mehregan). We acknowledge the Komarov Botanical Institute, H. Freitag, D. Podlech and K. Tamanian for providing plant material, O. Hidalgo, A. Ivashchenko, L. Kapustina, I. Kudratov, K. Romashchenko, J. Vallès, A. Mohagheghzadeh and S.A. Emami for their help in collecting material, Miquel Veny who carefully maintained the collection of living Cousinia at Barcelona, and finally Ch. Uhink for help with parts of the data analysis.

\section{LITERATURE CITED}

Andreasen, K. \& Baldwin, B.G. 2001. Unequal evolutionary rates between annual and perennial lineages of checker mallows (Sidalcea, Malvaceae): evidence from 18S-26S rDNA internal and external transcribed spacers. Molec. Biol. Evol. 18: 936-944.

Aryavand, A. 1975. Contribution à l'étude cytotaxonomique de quelques angiospermes de l'Iran. Bot. Not. 128: 299-311.

Boissier, E. 1875. Flora Orientalis, vol. 3. H. Georg, Geneva.

Boissier, E. 1888. Flora Orientalis Supplementum. R. Buser, Geneva, Basel, Lyon.

Bousquet, J., Strauss, S.H., Doerksen, A.H. \& Price, R.A. 1992. Extensive variation in evolutionary rate of $r b c L$ gene sequences among seed plants. Proc. Natl. Acad. Sci. U.S.A. 89: 7844-7848.

Bunge, A. von. 1865. Übersichtliche Zusammenstellung der Arten der Gattung Cousinia Cass. Mém. Acad. Imp. Sci. St.-Pétersbourg, Sér 7, 9: 1-56.

Candolle, A.P. de. 1838. Cousinia. Pp. 552-557 in: Prodromus systematis naturalis regni vegetabilis. Treuttel \& Würtz, Paris.

Cassini, A.H.G. 1827. Carlinées-Prototypes. Pp. 498-505 in: Cuvier, G.-F. (ed.), Dictionnaire des Sciences Naturelles, vol. 47. L. Levrault, Strasbourg.

Cronn, R.C., Small, R.L., Haselkorn, T. \& Wendel, J.F. 2002. Rapid diversification of the cotton genus (Gossypium: Malvaceae) revealed by analysis of sixteen nuclear and chloroplast genes. Amer. J. Bot. 89: 707-725.

Culling, K.W. 1992. Design and testing of plant-specific PCR primer for ecological and evolutionary studies. Molec. Ecol. 1: 223-240.

Dittrich, M. 1977. Cynareae-systematic review. Pp. 999-1015 in: Heywood, V.H., Harborne, J.B. \& Turner, B.L. (eds.), The Biology and Chemistry of the Compositae, vol. 2. Academic Press, London.

Doyle, J.J. \& Doyle, J.L. 1987. A rapid DNA isolation procedure for small quantities of fresh leaf tissue. Phytochem. Bull. 19: 11-15.

Duistermaat, H. 1996. Monograph of Arctium L. (Asteraceae). Generic delimitation (including Cousinia Cass. p. p.), revision of the species, pollen morphology and hybrids. Gorteria 3: 1-143.

Duistermaat, H. 1997. Arctium getting entangled to Cousinia (Asteraceae: Cardueae). Bocconea 5: 685-689.

Farris, J.S., Källersjö, M., Kluge, A.M. \& Bult, C. 1994. Testing significance of incongruence. Cladistics 10: 315-319.

Felsenstein, J. 1985. Confidence limits on phylogenies: an approach using the bootstrap. Evolution 39: 783-791.

Felsenstein, J. 1988. Phylogenies from molecular sequences: 
inference and reliability. Annual Rev. Genet. 22: 521565.

Font, M., Garnatje, T., Garcia-Jacas, N. \& Susanna, A. 2002. Delineation and phylogeny of Centaurea sect. Acrocentron based on DNA sequences: a restoration of the genus Crocodylium and indirect evidence of introgression. Pl. Syst. Evol. 234: 15-26.

Frackman, S., Kobs, G., Simpson, D. \& Storts, D. 1998. Betaine and DMSO: enhancing agents for PCR. Promega Notes 65: 27-29.

Frenzel, B., Pécsi, M. \& Velichko, A.A. 1992. Atlas of Paleoclimates and Paleoenvironments of the Northern Hemisphere. Geographical Research Institute, Hungarian Academy of Sciences, Budapest; Gustav Fischer Verlag, Stuttgart.

Frodin, D.G. 2004. History and concepts of big plant genera. Taxon 53: 753-776.

Garcia-Jacas, N., Garnatje, T., Susanna, A. \& Vilatersana, R. 2002. Tribal and subtribal delimitation and phylogeny of the Cardueae (Asteraceae): a combined nuclear and chloroplast DNA analysis. Molec. Phylog. Evol. 22: 51-64.

Garcia-Jacas, N., Susanna, A., Garnatje, T. \& Vilatersana, R. 2001. Generic delimitation and phylogeny of the subtribe Centaureinae (Asteraceae): a combined nuclear and chloroplast DNA analysis. Ann. Bot. 87: 503-515.

Garnatje, T., Susanna, A., Garcia-Jacas, N. \& Vilatersana, R. \& Vallès, J. 2005. A first approach to the molecular phylogeny of the genus Echinops (Asteraceae): Sectional delimitation and relationships with the genus Acantholepis Less. Folia Geobot. 40: 407-419.

Ghaffari, S.M., Garcia-Jacas, N. \& Susanna, A. 2006. New chromosome counts in the genus Cousinia (Asteraceae) from Iran. Bot. J. Linn. Soc. 151: 411-419.

González-Albaladejo, R., Fuertes, J., Aparicio, A. \& Nieto, G. 2005. Contrasting nuclear-plastidial phylogenetic patterns in the recently diverged iberian Phlomis crinita and P. lychnitis L. lineages (Lamiaceae). Taxon 54: 987-998.

Häffner, E. \& Hellwig, F.H. 1999. Phylogeny of the tribe Cardueae (Compositae) with emphasis on the subtribe Carduinae: an analysis based on ITS sequence data. Willdenowia 29: 27-39.

Häffner, E. 2000. On the phylogeny of the subtribe Carduinae (tribe Cardueae, Compositae). Englera 21: 1-209

Huelsenbeck, J.P. \& Ronquist, F.R. 2001. MrBAYES: Bayesian inference of phylogenetic trees. Bioinformatics 17: 754-755.

Kadereit, J.W., Griebeler, E.M. \& Comes, H.P. 2004. Quaternary diversification in European alpine plants-pattern and process. Philos. Trans., Ser. B 359: 265-274.

Kay, K.M., Whittall, J.B. \& Hodge, S.A. 2006. A survey of nuclear ribosomal internal transcribed spacer substitution rates across angiosperms: an approximate molecular clock with life history effects. BMC Evol. Biol. 6: 36, doi: 10.1186/1471-2148-6-36.

Knapp, H.D. 1987. On the distribution of the genus Cousinia (Compositae). Pl. Syst. Evol. 155: 15-25.

Kuntze, O. 1891. Revisio generum plantarum, vol. 1: 306-308. A. Felix, Leipzig.

Kuprianova, L.A. \& Tscherneva, O.V. 1982. Morfologija pyl’tzy I ultraskulptura palinodermy vidov roda Cousinia (Asteraceae) v svjazi s sistematikoi roda [Pollen morphology and ultrastructure of palynoderma in the species of the genus Cousinia (Asteraceae) in relation to the systematics of the genus]. Bot. Zhurn. (Moscow \& Leningrad) 67: 581-589.

Laroche, J., Li, P., Magia, L. \& Bousquet, J. 1997. Molecular evolution of angiosperm mitochondrial introns and exons. Proc. Natl. Acad. Sci. U.S.A. 94: 5722-5727.

Lidén, M., Fukuhara, T., Rylander, J. \& Oxelman, B. 1997. Phylogeny and classification of Fumariaceae, with emphasis on Dicentra s.l., based on the plastid gene rps16 intron. Pl. Syst. Evol. 206: 411-420.

Mabberley, D.J. 2008. Mabberley’s Plant Book, ed. 3. Cambridge University Press, Cambridge.

Maddison, W.P. \& Maddison, D.R. 2000. MacClade: Analysis of Phylogeny and Character Evolution, version 4.0. Sinauer, Sunderland.

Mai, D. 2001. Die mittelmiozänen und obermiozänen Floren aus der Meuroer und Raunoer Folge in der Lausitz. Teil III: Fundstellen und Paläobiologie. Palaeontographica, Abt. B, Paläophytol. 258: 1-85.

Mehregan, I. \& Kadereit, J.W. 2008. Taxonomic revision of Cousinia sect. Cynaroideae (Asteraceae, Cardueae). Willdenowia 38: 293-362.

Mehregan, I. \& Kadereit, J.W. In press. The role of hybridization in the evolution of Cousinia s.s. (Asteraceae). Willdenowia.

Meusel, H., Jäger, E. \& Weinert, E. 1965. Vergleichende Chorologie der zentraleuropäischen Flora, vol. 1. Fischer, Jena.

Morrison, D. 2007. Accelerating Maximum-likelihood Searches Using PAUP*. Department of Parasitology (SWEPAR), National Veterinary Institute and Swedish University of Agricultural Sciences, Uppsala, Sweden.

Muir, G. \& Schlötterer, C. 1999. Limitations to the phylogenetic use of ITS sequences in closely related species and populations - a case study in Quercus petraea (Matt.) Liebl. Chapter 11 in: Gillet, E.M. (ed.), Which DNA Marker for Which Purpose? Final Compendium of the Research Project "Development, optimization and validation of molecular tools for assessment of biodiversity in forest trees" in the European Union DGXII Biotechnology FW IV Research Program Molecular Tools for Biodiversity. Wiedebusch, Hamburg.

Nieto-Feliner, G., Fuertes-Aguilar, J. \& Rosselló, J.A. 2001. Can extensive reticulation and concerted evolution result in a cladistically structured molecular dataset? Cladistics 17: 301-312.

Nixon, K.C. 1999. The Parsimony Ratchet, a new method for rapid parsimony analysis. Cladistics 15: 407-414.

Nylander, J.A.A. 2004. MrModeltest, v2.2. Program distributed by the author. Evolutionary Biology Centre, Uppsala University, Uppsala.

Petit, D.P. 1997. Generic interrelationships of the Cardueae (Compositae): a cladistic analysis of morphological data. Pl. Syst. Evol. 207: 173-203.

Petit, D.P., Mathez, J. \& Qaid, A. 1996. Early differentiation of the Cardueae sensu lato: morphology and pollen. Pp. 79-93 in: Hind, D.J.N. \& Beentje, H.J. (eds.), Proceedings of the International Compositae Conference, Kew, 1994, vol. 1, Compositae Systematics. Royal Botanic Gardens, Kew.

Posada, D. \& Crandall, K.A. 1998. Modeltest: testing the model of DNA substitution. Bioinformatics 14: 817-818. 
Posada, D. \& Crandall, K.A. 2001. Selecting the best-fit model of nucleotide substitution. Syst. Biol. 50: 580-601.

Punt, W. \& Hoen, P.P. 2009. The Northwest European Pollen Flora, 70. Asteraceae - Asteridae. Rev. Paleobot. Palynol. Available at http://www.bio.uu.nl/ palaeo/research/NEPF/ nepf.htm.

Rechinger, K.H. 1953. Cousinia-Studien. Österr. Bot. Z. 100: 437-477.

Rechinger, K.H. 1972. Compositae-Cynareae I: Cousinia. Pp. 1-329 in: Rechinger, K.H. (ed.), Flora Iranica, vol. 90. Akademische Druck- und Verlagsanstalt, Graz.

Rechinger, K.H. 1979. Compositae-Cynareae III: Cousinia. Pp. 105-156 in: Rechinger, K.H. (ed.), Flora Iranica, vol. 90. Akademische Druck- und Verlagsanstalt, Graz.

Rechinger, K.H. 1986. Cousinia-morphology, taxonomy and phytogeographic implications. Proc. Roy. Soc. Edinburgh, B 89: 45-58.

Schtepa, I.S. 1966. K voprosu o svjazi rodov Arctium L. i Cousinia Cass. sem. Compositae [On the problem of the affinity between the genera Arctium L. \& Cousinia Cass. of the family Compositae]. Pp. 35-36 in: Nejshtadt, M.I. (ed.), The Importance of Palynological Analysis for the Stratigraphy and Paleofloristic Investigation. Academy of Sciences "Nauka", Moscow.

Schtepa, I.S. 1976. Palinologicheskoe issledovanie vidov seksii Eriocousinia roda Cousinia Cass. (Compositae) [Palynological investigation of Cousinia sect. Eriocousinia (Compositae)]. Pp. 31-33 in: Zaklinskaj, E.D. \& Nejshtadt, M.I. (eds.), Proceedings of the 4th International Palynological Conference. Academy of Sciences of the USSR, Leningrad.

Shaw, J., Lickey, E.B., Beck, J.T., Farmer, S.B., Liu, W., Miller, J., Siripun, K.C., Winder, C.T., Schilling, E.E. \& Small, R.L. 2005. The tortoise and the hare II: ^relative utility of 21 noncoding chloroplast DNA sequences for phylogenetic analysis. Amer. J. Bot. 92: 142-166.

Sikes, D.S. \& Lewis, P.O. 2001. Beta Software, Version 1. PAUPRat: PAUP* Implementation of the Parsimony Ratchet. Distributed by the authors. Department of Ecology and Evolutionary Biology, University of Connecticut, Storrs.

Suárez-Santiago, V.N., Salinas, M.J., Garcia-Jacas, N., Soltis, P.S., Soltis, D.E. \& Blanca, G. 2007. Evolution by reticulation of the Acrolophus subgroup (Centaurea L., Compositae) in the occidental Mediterranean: origin and diversification of the section Willkommia Blanca. Molec. Phylog. Evol. 43: 156-172.

Susanna, A. \& Garcia-Jacas, N. 2007. Tribe Cardueae. Pp. 123-146 in: Kadereit, J.W. \& Jeffrey, C. (eds.), The Families and Genera of Vascular Plants, vol. 8, Flowering Plants. Eudicots. Asterales. Springer, Berlin \& Heidelberg.

Susanna, A., Garcia-Jacas, N., Hidalgo, O., Vilatersana, R. \& Garnatje, T. 2006. The Cardueae (Compositae) revisited: insights from ITS, trnL-trnF, and matK nuclear and chloroplast DNA analysis. Ann. Missouri Bot. Gard. 93: 150-171.

Susanna, A., Garcia-Jacas, N., Vilatersana, R. \& Garnatje, T. 2003a. Generic boundaries and evolution of characters in the Arctium group: a nuclear and chloroplast DNA analysis. Collect. Bot. (Barcelona) 26: 101-118.
Susanna, A., Garcia-Jacas, N., Vilatersana, R., Garnatje, T., Vallès, J. \& Ghaffari, S.M. 2003b. New chromosome counts in the genus Cousinia and the related genus Schmalhausenia (Asteraceae, Cardueae). Bot. J. Linn. Soc. 43: 411-418.

Swofford, D.L. 2002. PAUP*: Phylogenetic Analysis Using Parsimony (*and Other Methods), version 4.0b 10. Sinauer, Sunderland.

Swofford, D.L. \& Olsen, G.J. 1990. Phylogeny reconstruction. Pp. 411-501 in Hillis, D.M. \& Moritz, C. (eds.), Molecular Systematics. Sinauer, Sunderland.

Taberlet, P., Gielly, L., Pautou, G. \& Bouvet, J. 1991. Universal primers for amplification of three non-coding regions of chloroplast DNA. Pl. Molec. Biol. 17: 1105-1109.

Tscherneva, O.V. 1962. Cousinia Cass. Pp. 108-357 in: Shishkin, B.K. (ed.), [Flora of the U.S.S.R.], vol. 27: Akademiya Nauk, Leningrad.

Tscherneva, O.V. 1982. Rod Hypacanthium (Asteraceae) i ego predstaviteli v Srednej Asii [The genus Hypacanthium (Asteraceae) and its representatives in Middle Asia]. Bot. Zhurn. (Moscow \& Leningrad) 68: 632-635.

Tscherneva, O.V. 1985. Chisla khromosom vidov roda Cousinia (Asteraceae) flory SSSR [Chromosome numbers in the species of the genus Cousinia (Asteraceae) in the flora of the U.S.S.R.]. Bot. Zhurn. (Moscow \& Leningrad) 70: 855-857.

Tscherneva, O.V. 1988a. Novye nadvidovye taksony roda Cousinia (Asteraceae) [New supraspecific taxa of the genus Cousinia (Asteraceae)]. Bot. Zhurn. (Moscow \& Leningrad) 73: 594-597.

Tscherneva, O.V. 1988b. Konspekt sistemy roda Cousinia Cass. (Asteraceae) flory SSSR [A synopsis of the Cousinia (Asteraceae) genus system in the flora of the U.S.S.R.]. Bot. Zhurn. (Moscow \& Leningrad) 73: 870-876.

Tscherneva, O.V. 1988c. The Cousinia of the SSSR. Akademiya Nauk, Leningrad. [In Russian]

Vilatersana, R., Martín-Villodre, J., Susanna, A., GarciaJacas, N. \& Garnatje, T. 2001. Pollen studies in subtribe Centaureinae (Asteraceae): the Carthamus complex and the genus Aegialophila analyzed with electron microscopy. Pl. Biol. 3: 607-615.

Vriesendorp, B. \& Bakker, F.T. 2005. Reconstructing patterns of reticulate evolution in angiosperms: What can we do? Taxon 54: 593-604.

Winkler, C. 1892. Synopsis specierum generis Cousiniae. Trudy Imp. S.-Peterburgsk. Bot. Sada 12: 181-286.

Winkler, C. 1897. Mantissa synopsis specierum generis Cousiniae. Trudy Imp. S.-Peterburgsk. Bot. Sada 14: 187-243.

Zhang, M.-L., Uhink, C.H. \& Kadereit, J.W. 2007. Phylogeny and biogeography of Epimedium/Vancouveria (Berberidaceae): Western North American-East Asian disjunctions, the origin of European mountain plant taxa, and East Asian species diversity. Syst. Bot. 32: 81-92.

Zharkikh, A. 1994. Estimation of evolutionary distances between nucleotide sequences. J. Molec. Evol. 39: 315-329.

Zohary, M. 1973. Geobotanical Foundations of the Middle East. Gustav Fischer Verlag, Stuttgart; Swets \& Zeitlinger, Amsterdam. 
Appendix 1. Species included in the molecular analysis with voucher information and GenBank accession numbers (ITS1; ITS2; rpS4-trnT-trnL). For all species of Cousinia the subgeneric classification is given. An asterisk (*) indicates sequences previously published.

Hypacanthium echinopifolium (Bornm.) Juz., Kyrgyzstan: Sine loc., Iljin s.n. (LE), AY373746*; AY373713*; EU661125. Jurinea albicaulis Bunge, Greece: Makedonia, Halkidiki, between Arnea and Paleokastro, Susanna 1957 \& al. (BC), AY373747*; AY373714*; EU661092. Jurinea humilis DC., Spain: Huesca, Plan, La Barana, P. Montserrat s.n. (JACA), L35868*; EU661093. Saussurea elegans Ledeb., Kazakhstan: Aksu-Dzabagly reservation, 1,800 m, Susanna 2179 \& al. (BC), AY373750*; AY373717*; EU661090. Saussurea maximowiczii Herder, Japan: Ofuna Botanical Garden, AY373751*; AY373718*; EU661091. Schmalhausenia nidulans (Regel) Petrak, Kazakhstan: Almatinskaya oblast, Alatau mt., above Almaty, Susanna 2088 \& al. (BC), AY373752*; AY373719*; EU661124. Tiarocarpus hymenostephanus Rech. f., Afghanistan: W, Herat, Band-e Farsi, 10 SW Farsi, 3,200 m, Freitag 6841 (KAS), EU923831; EU923945; EU661139. Tiarocarpus neubaueri (Rech. f.) Rech. f., Afghanistan: C, Bamian, Band-i Amir, Hochfächen, 3,000 m, Dieterle 896 (M), EU923775; EU923889; EU661140. Arctium lappa L., Iran: NNE, Khorassan: 25 SW Bodjnourd, 1,500 m, Mehregan 140 (MJG), EU923773; EU923887; EU661123. Arctium leiospermum Juz. \& C. Serg., Kazakhstan: Zambylskaya oblast, Kurdai pass, 900 m, Susanna 2154 \& al. (BC), AY373720*; AY373687*; EU661121. Arctium minus (Hill.) Bernh., Belgium: Lovaina Botanical Garden, AF19049*; AF19103*; EU661122. Cousinia oopoda Juz. (subg. Cousinia sect. Actinia Bunge), Tajikistan: South Tajikistan, west mountainside, Khodzha-Kazjyan range, Koy-Pjez-Tau mt., limestone outcrops, 1,240 m, Kinzikaeva 3585 (LE), EU923839; EU923953; EU661232. Cousinia tashkurghanica Rech. f. (subg. Cousinia sect. Actinia Bunge), Afghanistan: N, Mazar Sharif, Tang-e Sayyad, S of Tashkurghan, 600 m, Freitag 3905 (KAS), EU923777; EU923891; EU661234. Cousinia oligocephala Boiss. (subg. Cousinia sect. Albidae Rech. f.), Iran: Fars, Inter Shiraz and Sepidan, Shoul pass, 2,000 m, Mehregan 218 (MJG), EU923796; EU923910; EU661208. Cousinia chrysantha Kult. (subg. Cousinia sect. Alpinae Bunge), Kazakhstan: Shimkientskaya oblast, Aksu Dzabagly reservation, Darbassa canyon, 1,840 m, Susanna 2198 \& al. (BC), AY373725*; AY373692*; EU661136. Cousinia dipterocarpa Bornm. \& Rech. f. (subg. Cousinia sect. Alpinae Bunge), Iran: Khorassan, 27 km from Ghouchan to Bajgiran, Alam Ali pass, 1,820 m, Mehregan 167 (MJG), EU923862; EU923976; EU661155. Cousinia lasiolepis Boiss. (subg. Cousinia sect. Alpinae Bunge), Iran: Yasoudj, Dena mts., Bizhan Pass, 3,300 m, Mehregan 202 (MJG), EU923863; EU923977; EU661177. Cousinia multiloba DC. (subg. Cousinia sect. Alpinae Bunge), Iran: Khorassan, SW Bodjnourd, Salouk mt., 2,200 m, Mehregan 189 (MJG), EU923835; EU923949; EU661202. Cousinia serawschanica C. Winkl. (subg. Cousinia sect. Alpinae Bunge), Tajikistan: Voru, 2,000-2,300 m, Susanna 2516 \& al. (BC), EU923874; EU923988; EU661192. Cousinia splendida C. Winkl. (subg. Cousinia sect. Alpinae Bunge), Tajikistan: Fan mountains, road above Iskandar-Kul, 2,300 m, Susanna 2507 \& al. (BC), EU923871; EU923985; EU661197. Cousinia badghysi Kult. (subg. Cousinia sect. Badghysia Tschern.), Turkmenistan: Badghys, Eroylanduz lake, SE “sopki” Kazan, Kamelin 360 (LE), EU923872; EU923986; EU661166. Cousinia piptocephala Bunge (subg. Cousinia sect. Badghysia Tschern.), Iran: Isfahan, 5km from Mourcheh Khort towards Natanz, 1,500 m, Mehregan 188 (MJG), EU923801; EU923915; EU661204. Cousinia ariana Bornm. (subg. Cousinia sect. Carduncellus (Juz.) Rech. f.), Afghanistan: E, Kabul, N Salang, 3,150 m, Freitag 3494 (KAS), EU923788; EU923902; EU661221. Cousinia buphthalmoides Regel (subg. Cousinia sect. Carduncellus (Juz.) Rech. f.), Afghanistan: Unai-Pass, E side, 3,050 m, Freitag 6268 (KAS), EU923789; EU923903; EU661179. Cousinia tianschanica Kult. (subg. Cousinia sect. Carduncellus (Juz.) Rech. f.), Kazakhstan: Shimkientskaya oblast, Aksu Dzabagly reservation, Aksu canyon, Susanna 2191 \& al. (BC), AY373743*; AY373710*; EU661127. Cousinia dissecta Kar. \& Kir. (subg. Cousinia sect. Chrysoptera Tschern.), Kazakhstan: Almatinskaya oblast, Sugati mts., Kokpekti narrows, Susanna 2137 \& al. (BC), AY373728*; AY373695*; EU661141. Cousinia oxiana Tschern. (subg. Cousinia sect. Chrysoptera Tschern.), Afghanistan: NW, Herat, 34 km N of Shindand, 1,320 m, Amin 5252 (KAS), EU923854; EU923968; EU661227. Cousinia turkmenorum Bornm. (subg. Cousinia sect. Chrysoptera Tschern.), Iran: Khorassan, 20 km from Mashhad to Neishabour, 1,150 m, Mehregan 197 (MJG), EU923855; EU923969; EU661156. Cousinia greuteri Rech. f. (subg. Cousinia sect. Congesta Bunge), Afghanistan: N, Robatak pass between Haibak and Puli-Khumri, 1,400 m, Tonchev 2200 (KAS), EU923783; EU923897; EU661237. Cousinia coronata Franch. (subg. Cousinia sect. Coronophora (Juz.) Rech. f), Uzbekistan: road Tashkent-Samarkand, 10 km from the crossroads to Jizzak, 400 m, Susanna 2039 \& al. (BC), AY373727*; AY373694*; EU661178. Cousinia radians Bunge (subg. Cousinia sect. Coronophora (Juz.) Rech. f.), Iran: Khorassan, 66 km from Mashad to Kalat-Naderi, 1,000 m, Ghahreman \& al. s.n. (TUH), EU923791; EU923905; EU661217. Cousinia congesta Bunge (subg. Cousinia sect. Cousinia), Uzbekistan: between Samarkand and Kitov, Takhta-Karachi pass, 1,600 m, Susanna 2059 \& al. (BC), AY373726*; AY373693*; EU661131. Cousinia daralaghezica Takht. (subg. Cousinia sect. Cousinia), Armenia: Vajots Dzor, Eghegnadzor distr., Eghegnadzor town, Tamanian s.n. (ERE), EU923813; EU923927; EU661216. Cousinia intertexta Freyn \& Sint. (subg. Cousinia sect. Cousinia), Turkey: Sivas, DivrigiArapkir, 20 km S Divrigi, 1,410 m, Nydegger 17154 (M), EU923817; EU923931; EU661235. Cousinia meghrica Takht. (subg. Cousinia sect. Cousinia), Armenia: Sjunik, Meghri distr., Agarak village, Tamanian s.n. (ERE), EU923814; EU923928; EU661142. Cousinia minkwitziae Bornm. (subg. Cousinia sect. Cousinia), Kazakhstan: Zambylskaya oblast, Talaski Alatau, 6 km W from Il Tai, 1,000 m, Susanna 2183 \& al. (BC), AY373735*; AY373702*; EU661135. Cousinia polycephala Rupr. (subg. Cousinia sect. Cousinia), Kazakhstan: Zambylskaya oblast, $30 \mathrm{~km}$ from the Kurdai pass, Susanna 2161 \& al. (BC), AY373738*; AY373705*; EU661138. Cousinia syrdariensis Kult. (subg. Cousinia sect. Cousinia), Kazakhstan: Zambylskaya oblast, 30 km from the Kurdai pass, Susanna 2159 \& al. (BC), AY373741*; AY373708*; EU661133. Cousinia tenuifolia C.A. Mey. (subg. Cousinia sect. Cousinia), Iran: Azerbaijan, 10 km from Sarab to Ardebil, 1,400 m, Mehregan 186 (MJG), EU923812; EU923926; EU661171. Cousinia urumiensis Bornm. (subg. Cousinia sect. Cousinia), Iran: Azerbaijan, Urmia, inter Silvana and Razhan, 1,650 m, Mehregan 201 (MJG), EU923809; EU923923; EU661205. Cousinia araneosa DC. (subg. Cousinia sect. Cynaroideae Bunge), Iran: Hamedan, Alvand mt., 10 km from Hamedan to Toiserkan, Ganjnameh Valley, 2,400 m, Mehregan 219 (MJG), EU923870; EU923984; EU6611678. Cousinia macrocephala C.A. Mey. (subg. Cousinia sect. Cynaroideae Bunge), Iran: Azerbaijan, Arasbaran, Molouk pass, 1,500 m, Mehregan 212 (MJG), EU923852; EU923966; EU661169. Cousinia purpurea C.A. Mey. in DC. (subg. Cousinia sect. Cynaroideae Bunge), Armenia: Ararat, near the village of Shahap, roadsides, Tamanian s.n. (ERE), AY373739*; AY373706*; EU661137. Cousinia decumbens Rech. f. (subg. Cousinia sect. Decumbentes Rech. f.), Iran: Semnan, Shahroud, mt. Shahvar, SW Slopes, 3,600 m, 
Appendix 1. Continued.

Mehregan 110 (MJG), EU923821; EU923935; EU661157. Cousinia bungeana Regel \& Schmalh. (subg. Cousinia sect. Dichotomae Bunge), Sine loc.: Ovczinnikov 16104 (TAD), EU923786; EU923900; EU661130. Cousinia polytimetica Tschern. (subg. Cousinia sect. Dichotomae Bunge), Uzbekistan: Bukharskaya reg., deserted left bank of Zeravshan river, to SE from Uzlishkent vil., Kryakin s.n. (LE), EU923785; EU923899; EU661244. Cousinia pusilla C. Winkl. (subg. Cousinia sect. Dichotomae Bunge), Tajikistan: S Tajikistan, spackled rock mountains to the S from Besharcha mts. to Babatag range, Botschantzev 117 (LE), EU923787; EU923901; EU661189. Cousinia auriculata Boiss. (subg. Cousinia sect. Eriocousinia Tschern.), Afghanistan: E, Parvan, Ghowrband, SorkhParsa, 2,050 m, Freitag 1128 (KAS), EU923830; EU923944; EU661191. Cousinia chionophila Rech. \& Koie (subg. Cousinia sect. Eriocousinia Tschern.), Afghanistan: SE, Ghazni, mts. SE of Dashti Nawor (Sperlu Buli), 3,850 m, Freitag 1478 (KAS), EU923829; EU923943; EU661247. Cousinia gmelini C. Winkl. (subg. Cousinia sect. Eriocousinia Tschern.), Iran: Kandevan to Yoush, Djavadi s.n. (IRAN), EU923842; EU923956; EU661207. Cousinia polyneura Rech. f. (subg. Cousinia sect. Eriocousinia Tschern.), Afghanistan: E, Kabul, mts. above Paghman, 4,000 m, Freitag 3555 (KAS), EU923781; EU923895; EU661231. Cousinia xanthacantha Regel (subg. Cousinia sect. Eriocousinia Tschern.), Afghanistan: Kabul, in dec. orient. jugi Unai, Breckle 2286 (M), EU923778; EU923892; EU661230. Cousinia harazensis Rech. f. (subg. Cousinia sect. Harazensis Rech. f.), Iran: Mazandaran, Haraz road, Rineh, 1,900 m, Mehregan 175 (MJG), EU923825; EU923939; EU661146. Cousinia gatchsaranica I. Mehregan, Assadi \& Attar (subg. Cousinia sect. Haussknechtii Rech. F.), Iran: Gachsaran, N slopes of Khami mt., above Tol Chegah, 2,100 m, Mehregan 83246 (MJG), EU923816; EU923930; EU661159. Cousinia heliantha Bunge (subg. Cousinia sect. Helianthae Bunge), Iran: Khorassan, 30 km from Sabzevar to Esferaien, 1,550 m, Mehregan 170 (MJG), EU923810; EU923924; EU661172. Cousinia coerulea Kult. ex Tschern. (subg. Cousinia sect. Homalochaete C. Winkl.), Tajikistan: Vorzov canyon, Kudratov, Susanna 2459 \& al. (BC), EU923873; EU923987; EU661144. Cousinia crassipes Kult. (subg. Cousinia sect. Homalochaete C. Winkl.), Iran: Khorassan, Kalat-e Naderi, Ghareh-Sou, 1,400 m, Mehregan 144 (MJG), EU923811; EU923925; EU661143. Cousinia podophylla Tschern. (subg. Cousinia sect. Homalochaete C. Winkl.), Sine loc., Ouchinniku 258 (TAD), EU923847; EU923961; EU661233. Cousinia raddeana C. Winkl. (subg. Cousinia sect. Hoplophylla Tschern.), Iran: Khorassan, Mashhad, Kalat-e Naderi road, Sanganeh, Chahchaheh, 1,600 m, Ghahreman \& al. 27315 (TUH), EU923853; EU923967; EU661194. Cousinia immitantiformis Rech.f (subg. Cousinia sect. Immitantes Rech. f.), Afghanistan: NW, Sabzak pass, NE Herat, 2,400 m, Freitag 6784 (KAS), EU923846; EU923960; EU661149. Cousinia salangensis Rech. f. (subg. Cousinia sect. Immitantes Rech. f.), Afghanistan: E, Kabul, S Salang valley, marble area, 2,500 m, Freitag 3490 (KAS), EU923845; EU923959; EU661134. Cousinia jassyensis C. Winkl. (subg. Cousinia sect. Jurineopsis (Juz.) Tschern.), Kyrgyzstan: SW, Jalal Abad Oblast, Toktogul Rayoh, 790 m, Martins 872 (JE), EU923790; EU923904; EU661240. Cousinia smirnowii Trautv. (subg. Cousinia sect. Kopetdagia Tschern.), Iran: Khorassan, SW Bodjnourd, Salouk mt., 2,300 m, Mehregan 152 (MJG), EU923802; EU923916; EU661154. Cousinia chrysochlora Rech. f. \& Koeie (subg. Cousinia sect. Lachnosphaerae Rech. f.), Iran: Khorassan, 30 km from Sedeh to Asad Abad, Mahousak, 2,000 m, Mehregan 198 (MJG), EU923856; EU923970; EU661148. Cousinia lachnosphaera Bunge (subg. Cousinia sect. Lachnosphaerae Rech. f.), Iran: Khorassan, 40 km from Gonabad to Ferdous, 1,900 m, Mehregan 145 (MJG), EU923857; EU923971; EU661209. Cousinia alepideae Boiss. (subg. Cousinia sect. Lasiandrae Bunge), Afghanistan: SW, Ghazni, Jamroud, 45 km SW of Ghazni, 2,010 m, Freitag 2008 (KAS), EU923794; EU923908; EU661182. Cousinia lasiandra Bunge (subg. Cousinia sect. Lasiandrae Bunge), Iran: Khorassan, 3 km from Doust Abad to Birjand, 1,500 m, Mehregan 127 (MJG), EU923822; EU923936; EU661185. Cousinia triceps Kult. (subg. Cousinia sect. Leiacanthos Tschern.), Uzbekistan: Kughitang range, Tanghydevol canyon, rocky area, 870 m, Kamelin 870 (LE), EU923784; EU923898; EU661129. Cousinia antonowii C. Winkl. (subg. Cousinia sect. Leiocaules Bunge), Iran: Khorassan, 10 km from Tivan to Bajgiran, 1,590 m, Mehregan 196 (MJG), EU923849; EU923963; EU661200. Cousinia arctotidifolia Bunge (subg. Cousinia sect. Leiocaules Bunge), Iran: Khorassan, Shirvan, $10 \mathrm{~km}$ from Ziarat to Lojelli, 1,215 m, Mehregan 120 (MJG), EU923848; EU923962; EU661165. Cousinia heterophylla Boiss. (subg. Cousinia sect. Lepidae Bunge), Afghanistan: W, N-Kattawz, between Kotanni-Kotal and Patanna, 2,150 m, Freitag 3345 (KAS), EU923804; EU923918; EU661184. Cousinia lepida (Bunge ex) Boiss. (subg. Cousinia sect. Lepidae Bunge), Iran: Khorassan, Esferaien, 5 km Dahaneh Ojagh to Esferaien, 1,420 m, Mehregan 114 (MJG), EU923805; EU923919; EU661183. Cousinia linczewskii Juz. (subg. Cousinia sect. Leucocaulon Tschern.), Iran: Khorassan, Inter Mashhad and Sarakhs, Mazd-Avand pass, 1,000 m, Mehregan 138 (MJG), EU923850; EU923964; EU661153. Cousinia turcomanica C. Winkl. (subg. Cousinia sect. Leucocaulon Tschern.), Iran: Khorassan, $110 \mathrm{~km}$ W of Bojnourd, between Spakhou and Kastan, 2,000 m, Mehregan 105 (MJG), EU923834; EU923948; EU661174. Cousinia rigida Kult. (subg. Cousinia sect. Lopholepis Tschern.), Kyrgyzstan: Talasskaya reg., north mountainside of Talassky Alatau, Kur-Bokair canyon, south rocky slope, Popova s.n. (LE), EU923869; EU923983; EU661222. Cousinia arachnoidea Fisch. \& C.A. Mey. (subg. Cousinia sect. Microcarpae Bunge), Kazakhstan: Almatinskaya oblast, Malai Sary pass, 700 m, Susanna 2140 \& al. (BC), AY373722*; AY373689*; EU661248. Cousinia ninae Juz. (subg. Cousinia sect. Microcarpae Bunge), Kyrgyzstan: Oshskaya, Torgulsky reg., Oitaya area north from Shoporovo vil., speckled soils, Sultanova s.n. (LE), EU923868; EU923982; EU661224. Cousinia platylepis Schrenk. ex Fisch. \& C.A. Mey. (subg. Cousinia sect. Microcarpae Bunge), Kazakhstan: Zambylskaya oblast, 30 km from the Kurdai pass, Susanna 2158 \& al. (BC), AY373737*; AY373704*; EU661236. Cousinia sewertzowii Regel (subg. Cousinia sect. Microcarpae Bunge), Kazakhstan: Aksu-Dzabagly reservation, 1,800 m, Susanna 2178 \& al. (BC), AY373740*; AY373707*; EU661175. Cousinia prolifera Jaub. \& Spach (subg. Cousinia sect. Microcousinia Tschern.), Iran: Khorassan, 110 km from Birjand to Ferdous, 1,500 m, Mehregan 233 (MJG), EU923779; EU923893; EU661245. Cousinia heteroloba Rech. f. (subg. Cousinia sect. Molles Schrenk.), Afghanistan: NE, Andarab valley below Khinjan, near Ghazan, 1,000 m, Freitag 3043 (KAS), EU923776; EU923890; EU661198. Cousinia candolleana Jaub. \& Spach. (subg. Cousinia sect. Myriotemae Rech. f.), Iran: Ghazvin, $10 \mathrm{~km}$ from Abgarm to Avadj, 1,950 m, Mehregan 239 (MJG), EU923858; EU923972; EU661195. Cousinia olgae Regel. \& Schmalh. (subg. Cousinia sect. Olgaeanthe Tschern.), Iran: Khorassan, 40 km from Torbat-e Djam to Saleh Abad, 1,550 m, Mehregan 194 (MJG), EU923780; EU923894; EU661203. Cousinia eriophylla (Kult.) Bornm. (subg. Cousinia sect. Platyacanthae Rech. f.), Iran: Khorassan, Inter Ghouchan and Bajgiran, 5 km S of Dorbadam, 1,500 m, Mehregan 190 (MJG), EU923840; EU923954; EU661160. Cousinia rechingerorum Bornm. (subg. Cousinia sect. Platyacanthae Rech. f.), Iran: Khorassan: $30 \mathrm{~km}$ W of Torbat-e Djam, E 
Appendix 1. Continued.

mt., 2,000 m, Mehregan 163 (MJG), EU923841; EU923955; EU66116. Cousinia trachyphyllaria Bornm. \& Rech. f. (subg. Cousinia sect. Platyacanthae Rech. f.), Iran: Khorassan, Neishabour, Khorw, 2,100 m, Mehregan 217 (MJG), EU923828; EU923942; EU661163. Cousinia apiculata Tschern. (subg. Cousinia sect. Pseudactinia Tschern.), Iran: Khorassan, Shirvan, Sarani, 2,300 m, Ghahreman \& Attar s.n. (MJG), EU923792; EU923906; EU661162. Cousinia oreodoxa Bornm. \& Sint. (subg. Cousinia sect. Pseudactinia Tschern.), Iran: Khorassan, Inter Bodjnourd and Raz, 7 km from Tangeh Torkeman to Ashkhaneh, 1,000 m, Mehregan 150 (MJG), EU923793; EU923907; EU661151. Cousinia belangeri DC. (subg. Cousinia sect. Pugioniferae Bunge), Iran: Tehran, 15 km to Karaj, 1,200 m, Mehregan s.n. (MJG), EU923819; EU923933; EU661210. Cousinia calcitrapa DC. (subg. Cousinia sect. Pugioniferae Bunge), Iran: Fars, pass inter Sepidan and Yassoudj, 20 km from Sepidan, 2,400 m, Mehregan 203 (MJG), EU923820; EU923934; EU661220. Cousinia incompta DC. (subg. Cousinia sect. Pugioniferae Bunge), Iran: 20 km Borujen to Isfahan, 2,400 m, Mehregan 128 (MJG), EU923851; EU923965; EU661186. Cousinia pineticola Rech. f. \& Gilli (subg. Cousinia sect. Racemosae Rech. f.), Afghanistan: E, Kabul, Korogh Koh, SW of Kabul, 2,600 m, Freitag 1568 (KAS), EU923832; EU923946; EU661107. Cousinia botschantzevii Juz. ex Tschern. (subg. Cousinia sect. Regelianae (Juz.) Tschern.), Uzbekistan: Kuramit mt., Koitash range, S slope above the Koitash village, 1,850 m, Kamelin 29 (LE), EU923782; EU923896; EU661250. Cousinia autranii C. Winkl. (subg. Cousinia sect. Rigidissimae Rech. f.), Afghanistan: W, Herat, Ghorat, Bande Frasi, 15 km SSE Farsi, 2,400-2,500 m, Freitag 6831 (KAS), EU923860; EU923974; EU661105. Cousinia rigidissima Rech. f. (subg. Cousinia sect. Rigidissimae Rech. f.), Afghanistan: W, Herat, Ghorat, in summo jugo 5 km S Dahan-e Kaftarkhan ad viam inter Tulak et Farsi, 2,350 m, Podlech 19193 (M), EU923861; EU923975; EU661187. Cousinia scariosa Regel (subg. Cousinia sect. Scariosae Rech. f.), Afghanistan: N, Sar-e Pol, Sangcharak, 40 km SSW mts. above Damdaran, 1,900-2,500 m, Freitag 6594 (KAS), EU923838; EU923952; EU661190. Cousinia eryngioides Boiss. (subg. Cousinia sect. Sciadocousinia Tschern.), Iran: Khorassan, 50 km from Mashhad to Neishabour, 1,500 m, Mehregan 168 (MJG), EU923836; EU923950; EU661164. Cousinia concolor Bunge (subg. Cousinia sect. Serratuloides Bunge), Iran: Semnan, Shahroud, S slopes of Shahvar mt., above Nekarmann, 2,500 m, Mehregan 158 (MJG), EU923808; EU923922; EU661150. Cousinia crispa Jaub. \& Spach. (subg. Cousinia sect. Serratuloides Bunge), Iran: Chalous road, $10 \mathrm{~km}$ from Kandavan to Chalous, 2,000 m, Mehregan 185 (MJG), EU923843; EU923957; EU661241. Cousinia hypoleuca Boiss. (subg. Cousinia sect. Serratuloides Bunge), Iran: Tehran, Inter Firouzkouh and Polur, 5 km W of Lasem, 2,500 m, Mehregan 177 (MJG), EU923807; EU923921; EU661176. Cousinia pinarocephala Boiss. (subg. Cousinia sect. Serratuloides Bunge), Iran: Tehran, Firouzkouh, Gadouk pass, 2,200 m, Mehregan 192 (MJG), EU923844; EU923958; EU661223. Cousinia adenosticta Bornm. (subg. Cousinia sect. Sphaerocephalae Bunge), Iran: Tehran, between Shemshak and Dizin, 3,000 m, Mehregan 165 (MJG), EU923827; EU923941; EU661110. Cousinia leptolepis (Bornm. \& Gauba) Rech. f. (subg. Cousinia sect. Sphaerocephalae Bunge), Iran: Tehran, Karadj, Kuh Dashteh, S slopes, 2,200 m, Mehregan 111 (MJG), EU923826; EU923940; EU661206. Cousinia shahvarica Rech.f. (subg. Cousinia sect. Sphaerocephalae Bunge), Iran: Semnan, Shahroud, mt. Shahvar, S slopes, 3,000 m, Mehregan 117 (MJG), EU923823; EU923937; EU661180. Cousinia xiphiolepis Boiss. (subg. Cousinia sect. Sphaerocephalae Bunge), Iran: Tehran, inter Firouzkouh and Polur, 5 km W of Lasem, 2,600 m, Mehregan 179 (MJG), EU923824; EU923938; EU661188. Cousinia longifolia C. Winkl. \& Bornm. (subg. Cousinia sect. Spinuliferae Rech. f.), Iran: Kerman, Laleh zar to Rabor, Attar 226 (MJG), EU923815; EU923929; EU661158. Cousinia qaisarensis Rech. f. (subg. Cousinia sect. Spinuliferae Rech.f.), Afghanistan: NW, Fariab, Maimana, Qaisar, 20 km, mts. above Shakh (Gala Shakh), 2,200 m, Freitag 6745 (KAS), EU923833; EU923947; EU661201. Cousinia alexeenkoana Bornm. (subg. Cousinia sect. Stenocephalae Bunge), Iran: Isfahan, $10 \mathrm{~km}$ from Khaansaar to Boein, 2,500 m, Mehregan 132 (MJG), EU923799; EU923913; EU661181. Cousinia cylinracea Boiss. (subg. Cousinia sect. Stenocephalae Bunge), Iran: Fars, inter Shiraz and Sepidan, Shoul pass, 2,000 m, Mehregan 213 (MJG), EU923797; EU923911; EU661108. Cousinia gaubae Bornm. (subg. Cousinia sect. Stenocephalae Bunge), Iran: Ghazvin, Karadj, in declivibus lapidosis, 1,400 m, Rechinger 5504 (M), EU923818; EU923932; EU661109. Cousinia tenuiramula Rech. f. (subg. Cousinia sect. Stenocephalae Bunge), Iran: Bakhtiari, Rokh pass, 2,200 m, Mehregan 206 (MJG), EU923798; EU923912; EU661214. Cousinia thamnodes Boiss. \& Hausskn. (subg. Cousinia sect. Stenocephalae Bunge), Iran: Gachsaran, Khami mt. above Tol Chegah, 3,170 m, Mehregan 237 (MJG), EU923800; EU923914; EU661212. Cousinia komarovii (O. Kuntze) C. Winkl. (subg. Cousinia sect. Stenoloma Juz.), Iran: Khorassan, 15 km Bajgiran to Ghouchan, 1,700 m, Mehregan 156 (MJG), EU923803; EU923917; EU661152. Cousinia leucantha Bornm. \& Sint. (subg. Cousinia sect. Stenoloma Juz.), Iran: Golestan Nat. Park, 12 km ENE of Tange Gol, 1,900-2,100 m, Akhani 11357 (M), EU923837; EU923951; EU661170. Cousinia stocksii C.Winkl. (subg. Cousinia sect. Stocksianae Rech. f.), Afghanista: W, Farah, Schucht, 1 km nördlich Hakumate Purchaman, 1,880 m, Podlech 21787 (M), EU923795; EU923909; EU661116. Cousinia tenella Fisch. \& C.A. Mey. (subg. Cousinia sect. Tenellae Bunge), Iran: Golestan Nat. Park, between Sharlegh and Cheshmeh Khan, Akhani 243 (MJG), EU923774; EU923888; EU661104. Cousinia chaetocephala Kult. (subg. Cousinia sect. unknown), Iran: Khorassan, Tchenaran, 3km from Meritchegan to Radekan, 1,500 m, Mehregan 115 (MJG), EU923806; EU923920; EU661145. Cousinia pallidivirens Kult. (subg. Cynaroides Tschern. unassigned to any section), Uzbekistan: Sine loc., Botschantzev s.n. (LE), EU923768; EU923882; EU661126. Cousinia chlorantha Kult. (subg. Cynaroides Tschern. sect. Chrysis Juz.), Uzbekistan: Malguzar mt., S slope, by Tashkesken "say”, Kamelin 199 (LE), EU923864; EU923978; EU661120. Cousinia karatavica Regel et Schmalh. (subg. Cynaroides Tschern. sect. Chrysis Juz.), Kazakhstan: Zambylskaya oblast, Karatau mt., Kuyuk pass, 1,000 m, Susanna 2162 \& al. (BC), AY373732*; AY373699*; EU661101. Cousinia korolkowii Regel \& Schmalh. (subg. Cynaroides Tschern. sect. Chrysis Juz.), Uzbekistan: N macro-mountainside, Nuratau range, Sintob kishlak surroundings, rocky slopes, Botschantzev 427 (LE), EU923865; EU923979; EU661103. Cousinia medians Juz. (subg. Cynaroides Tschern. sect. Chrysis Juz.), Uzbekistan: S, Supkhandarbinskaya reg., between kishlaks Sajrob and Shurob, 121-122 km of the road from Termez, Speckled rock outcrops, Botschantzev 240 (LE), EU923769; EU923883; EU661100. Cousinia refracta (Bornm.) Juz. (subg. Cynaroides Tschern. sect. Chrysis Juz.), Tajikistan: Kondara river canyon, Varzowski Rayon reservation, Susanna 2456 \& al. (BC), EU923867; EU923981; EU661111. Cousinia anomala Franch. (subg. Cynaroides Tschern. sect. Ctenarctium Juz.), Tajikistan: Slopes above Voru, about $300 \mathrm{~m}$ above Kishlak, 2,200-2,300 m, Susanna 2521 \& al. (BC), EU923770; EU923884; EU661115. Cousinia lappacea Schrenk (subg. Cynaroides Tschern. sect. Lappaceae Bunge), Kazakhstan: Zambylskaya oblast, Kurdai pass, 900 m, Susanna 2150 \& al. (BC), AY373733*; 
Appendix 1. Continued.

AY373700*; EU661112. Cousinia arctioides Schrenk (subg. Cynaroides Tschern. sect. Nanarctium Juz. ex. Tschern.), Kazakhstan: Dzhezkazganskaya reg., Turgajskaya lowland, 49 km to SW from Dzhezkazgana, right bank of Kumula river, Tamarix bushland, Kamelin 6434 (LE), EU923772; EU923886; EU661118. Cousinia triflora Schrenk (subg. Cynaroides Tschern. sect. Oligantha Juz.), Iran: Golestan Nat. Park, Yakhbala pass, Akhani 102 (MJG), EU923771; EU923885; EU661094. Cousinia albertii Regel et Schmalh. (subg. Cynaroides Tschern. sect. Pectinatae C. Winkl.), Kazakhstan: Shimkientskaya oblast, Mashat canyon, 1,840 m, Susanna 2206 \& al. (BC), AY373721*; AY373688*; EU661099. Cousinia amplissima (Boiss.) Boiss. (subg. Cynaroides Tschern. sect. Pseudarctium Juz.), Iran: Dena, 15 km from Meimand to Yassoudj, 2,500 m, Mehregan 174 (MJG), EU923766; EU923880; EU661098. Cousinia pseudarctium Bornm. (subg. Cynaroides Tschern. sect. Pseudarctium Juz.), Tajikistan: Vorzov valley, 2 km N kishlak Ziddy, Susanna 2477 \& al. (BC), EU923876; EU923990; EU661095. Cousinia tomentella C. Winkl. (subg. Cynaroides Tschern. sect. Pseudarctium Juz.), Tajikistan: S mountainside of Guissar range, left bank of Varzob river, Deamalik kishlak surroundings, 1,800 m, Tschukavina 10512 (LE), EU923767; EU923881; EU661097. Cousinia umbrosa Bunge (subg. Cynaroides Tschern. sect. Pseudarctium Juz.), Kazakhstan: Almatinskaya oblast, Alatau mt. above Almaty, 1,200 m, Susanna 2100 \& al. (BC), AY373745*; AY373712*; EU661096. Cousinia abolinii Kult. ex Tscherneva (subg. Hypacanthodes Tschern. sect. Abolinia Tschern.), Kyrgyzstan: SW, Jalal Abad Oblast, Kara Saj Tal, Aksy Rayan, 1,030 m, Lazkov s.n. (JE), EU923763; EU923877; EU661113. Cousinia dolichophylla Kult. (subg. Hypacanthodes Tschern. sect. Abolinia Tschern.), Uzbekistan: Ugamsky range above Nanaj, right edge of Pskem valley, "shiblyak", Kamelin 265 (LE), EU923875; EU923989; EU661117. Cousinia egregia Juz. (subg. Hypacanthodes Tschern. sect. Abolinia Tschern.), Uzbekistan: Angren valley, rise to Kamchik pass, rubby slope, Kamelin 420 (LE), EU923866; EU923980; EU661196. Cousinia grandifolia Kult. (subg. Hypacanthodes Tschern. sect. Amberbopsis Tschern.), Kazakhstan: Zambylskaya oblast, Talaski Alatau, 6 km W from Il Tai, 1,000 m, Susanna 2181 \& al. (BC), AY373730*; AY373697*; EU661114. Cousinia korshinskyi C. Winkl. (subg. Hypacanthodes Tschern. sect. Lacerae C. Winkl.), Kyrgyzstan: isolated terrain feature Kanka, upper waters of river Kanka, near snow pot, h. 2,300 m, E.M. Il'ina s.n. (LE), EU923765; EU923879; EU661102. Cousinia macilenta C. Winkl (subg. Hypacanthodes Tschern. sect. Lacerae C. Winkl.), Tajikistan: SW, Jugum Hissaricum (Gissar), divorticum aquarum inter flumina Ljuczob et Unou, 3,000 m, Zaprojagaev s.n. (M), EU923764; EU923878; EU661119.

Appendix 2. Geographical distribution and taxonomic composition of clades found in the BI analyses of the ITS, rps4trnT-trnL and combined ITS + rps4-trnT-trnL datasets. Numbers refer to clades or subclades of the Cousinioid group with PP $\geq 0.95$ in Figs. 2-4. Geographical distribution according to the eight main centres of diversity of Cousinia as shown in Fig. 1.

rps4-trnT-trnL: CLADE 1: C. pinarocephala, sect. Serratuloides, Reg. 3; C. crispa, sect. Serratuloides, Reg. 3. CLADE 2: C. araneosa, sect. Cynaroideae, Reg. 2; C. leucantha, sect. Stenoloma, Reg. 4; (NESTED SUBCLADE 2a: C. smirnowii, sect. Kopetdagia, Reg. 4; C. komarowii, sect. Stenoloma, Reg. 4; C. linczewskii, sect. Leucocaulon, Reg. 4; C. dipterocarpa, sect. Alpinae, Reg. 4; C. turkmenorum, sect. Chrysoptera, Reg. 4; C. decumbens, sect. Decumbentes, Reg. 4; C. eriophylla, sect. Platyacanthae, Reg. 4; C. rechingerorum, sect. Platyacanthae, Reg. 4; C. apiculata, sect. Pseudactinia, Reg. 4; C. trachyphyllaria, sect. Platyacanthae, Reg., 4; C. gatchsaranica, sect. Haussknechtii, Reg. 2; C. macrocephala, sect. Cynaroideae, Reg. 1; C. eryngioides, sect. Sciadocousinia, Reg. 3, 4; C. arctotidifolia, sect. Leiocaules, Reg. 4; C. badghysi, sect. Badghysia, Reg. 4; C. longifolia, sect. Spinuliferae, Reg. 4). CLADE 3: C. sewertzowii, sect. Microcarpae, Reg. 7; C. turcomanica, sect. Leucocaulon, Reg. 4. CLADE 4: C. serawschanica, sect. Alpinae, Reg. 7; C. raddeana, sect. Hoplophylla, Reg. 4, 5, 7; C. splendida, sect. Alpinae, Reg. 7; C. heteroloba, sect. Molles, Reg. 5, 6. CLADE 5: C. jassyensis, sect. Jurineopsis, Reg. 8; C. ninae, sect. Microcarpae, Reg. 7, 8; C. arachnoidea, sect. Microcarpae, Reg. 8; (NESTED SUBCLADE 5a: C. tianschanica, sect. Carduncellus, Reg. 8; C. triceps, sect. Leiacanthos, Reg. 7; C. platylepis, sect. Microcarpae, Reg. 5, 7, 8; C. greuteri, sect. Congesta, Reg. 5, 6; C. oopoda, sect. Actinia, Reg. 7; C. podophylla, sect. Homalochaete, Reg. 7; C. oxiana, sect. Chrysoptera, Reg. 4; C. xanthacantha, sect. Eriocousinia, Reg. 6; C. polyneura, sect. Eriocousinia, Reg. 6; C. tashkurghanica, sect. Actinia, Reg. 5; C. intertexta, sect. Cousinia, Reg. 1; C. chionophila, sect. Eriocousinia, Reg. 5; C. botschantzevii, sect. Regelianae, Reg. 7). ITS: CLADE 1: C. splendida, sect. Alpinae, Reg. 7; C. ariana, sect. Carduncellus, Reg. 5, 6; C. buphthalmoides, sect. Carduncellus, Reg. 5, 6, 7; C. sewertzowii, sect. Microcarpae, Reg. 7; C. ninae, sect. Microcarpae, Reg. 8, 7; C. jassyensis, sect. Jurineopsis, Reg. 8; (NESTED SUBCLADE 1a: C. coronata, sect. Coronophora, Reg. 7; C. radians, sect. Coronophora, Reg. 4). CLADE 2: C. tianschanica, sect. Carduncellus, Reg. 8; C. botschantzevii, sect. Regelianae, Reg.7. CLADE 3: C. polytimetica, sect. Dichotomae, Reg. 7; C. pusilla, sect. Dichotomae, Reg. 7; C. bungeana, sect. Dichotomae, Reg. 8. CLADE 4: C. minkwitziae, sect. Cousinia, Reg. 8; C. chrysantha, sect. Alpinae, Reg. 8; C. dissecta, sect. Chrysoptera, Reg. 8; (NESTED SUBCLADE 4a: C. syrdariensis, sect. Cousinia, Reg. 8; C. polycephala, sect. Cousinia, Reg. 7, 8). CLADE 5: C. serawschanica, sect. Alpinae, Reg. 7; C. polyneura, sect. Eriocousinia, Reg. 6. CLADE 6: C. hypoleuca, sect. Serratuloides, Reg. 3; C. concolor, sect. Serratuloides, Reg. 3, 4. CLADE 7: C. rigida, sect. Lopholepis, Reg. 8; (NESTED SUBCLADE 7a: C. stocksii, sect. Stocksianae, Reg. 4, 5; (NESTED SUBCLADE 7aa: C. tenuiramula, sect. Stenocephalae s.l, Reg. 2; C. piptocephala, sect. Badghysia, Reg. 2; C. thamnodes, sect. Stenocephalae s.l., Reg. 2; C. alexeenkoana, sect. Stenocephalae s.l., Reg. 2; C. cylindracea, sect. Stenocephalae s.l., Reg. 2; C. oligocephala, sect. Stenocephalae s.l., Reg. 2)); (NESTED SUBCLADE 7b: C. apiculata, sect. Pseudactinia, Reg. 4; C. oreodoxa, sect. Pseudactinia, Reg. 4); (NESTED SUBCLADE 7c: C. chaetocephala, sect. unknown, Reg. 4; C. lepida, sect. Lepidae, Reg. 4; C. heterophylla, sect. Lepidae, Reg. 4, 5). CLADE 8: C. gmelinii, sect. Serratuloides, Reg. 3; C. pinarocephala, sect. Serratuloides, Reg. 3; C. crispa, sect. Serratuloides, Reg. 3. CLADE 9: C. eriophylla, sect. Platyacanthae, Reg. 4; C. rechingerorum, sect. Platyacanthae, Reg. 4. CLADE 10: C. salangensis, sect. Immitantes, Reg. 6; C. immitantiformis, sect. Immitantes, Reg. 5; (NESTED SUBCLADE 10a: C. coerulea, sect. Homalochaete, Reg. 7; C. podophylla, 
Appendix 2. Continued.

sect. Homalochaete, Reg. 7). CLADE 11: C. incompta, sect. Pugioniferae, Reg. 2; (NESTED SUBCLADE 11a: C. purpurea, sect. Cynaroideae, Reg. 1; C. araneosa, sect. Cynaroideae, Reg. 2; C. macrocephala, sect. Cynaroideae, Reg. 1). CLADE 12: C. chrysochlora, sect. Lachnosphaerae, Reg. 4; C. lachnosphaera, sect. Lachnosphaerae, Reg. 4, 5. CLADE 13: C. turkmenorum, sect. Chrysoptera, Reg. 4; C. oxiana, sect. Chrysoptera, Reg. 4. CLADE 14: C. autranii, sect. Rigidissimae, Reg. 5; C. rigidissimae, sect. Rigidissimae, Reg. 5. CLADE 15: C. auriculata, sect. Eriocousinia, Reg. 5, 6, 7; C. chionophila, sect. Eriocousinia, Reg. 5. CLADE 16: C. shahvarica, sect. Sphaerocephalae, Reg. 3; (NESTED SUBCLADE 16a: C. harazensis, sect. Sphaerocephalae, Reg. 3; C. xiphiolepis, sect. Sphaerocephalae, Reg. 3); (NESTED SUBCLADE 16b: C. adenosticta, sect. Sphaerocephalae, Reg. 3; C. leptolepis, sect. Sphaerocephalae, Reg. 3). CLADE 17: C. decumbens, sect. Decumbentes, Reg.3; C. badphysi, sect. Badghysia, Reg. 4. CLADE 18: C. gatchsaranica, sect. Haussknechtii, Reg. 2; C. intertexta, sect. Cousinia, Reg. 1. Combined ITS + rps4-trnT-trnL: CLADE 1: C. polytimetica, sect. Dichotomae, Reg. 7; C. pusilla, sect. Dichotomae, Reg. 7; C. bungeana, sect. Dichotomae, Reg. 8. CLADE 2: C. chrysantha, sect. Alpinae, Reg. 8; C. dissecta, sect. Chrysoptera, Reg. 8; (NESTED SUBCLADE 2a: C. minkwitziae, sect. Cousinia, Reg. 8; C. syrdariensis, sect. Cousinia, Reg. 8; C. polycephala, sect. Cousinia, Reg. 7, 8). CLADE 3: C. splendida, sect. Alpinae, Reg. 7; C. ariana, sect. Carduncellus, Reg. 6, 5; (NESTED SUBCLADE 3a: C. buphthalmoides, sect. Carduncellus, Reg. 5, 6, 7; C. sewertzowii, sect. Microcarpae, Reg. 7; (NESTED SUBCLADE 3aa: C. jassyensis, sect. Jurineopsis, Reg. 8; C. ninae, sect. Microcarpae, Reg. 7, 8); (NESTED SUBCLADE 3ab: C. coronata, sect. Coronophora, Reg. 7; C. radians, sect. Coronophora, Reg. 4)). CLADE 4: C. hypoleuca, sect. Serratuloides, Reg. 3: C. concolor, sect. Serratuloides, Reg. 3, 4. CLADE 5: C. stocksii, sect. Stocksianae, Reg. 4, 5; C. komarowii, sect. Stenoloma, Reg. 4; C. alepideae, sect. Lasiandrae, Reg. 5; (NESTED SUBCLADE 5a: C. cylindracea, sect. Stenocephalae s.l., Reg. 2; C. oligocephala, sect. Stenocephalae s.l., Reg. 2; (NESTED SUBCLADE 5aa: C. tenuiramula, sect. Stenocephalae s.l, Reg. 2; C. piptocephala, sect. Badghysia, Reg. 2; C. thamnodes, sect. Stenocephalae s.l., Reg. 2; C. alexeenkoana, sect. Stenocephalae s.l., Reg. 2)). CLADE 6: C. chaetocephala, sect. unknown, Reg. 4; C. lepida, sect. Lepidae, Reg. 4; C. heterophylla, sect. Lepidae, Reg. 4, 5. CLADE 7: C. chrysochlora, sect. Lachnosphaerae, Reg. 4; C. lachnosphaera, sect. Lachnosphaerae, Reg. 4, 5. CLADE 8: C. gmelinii, sect. Serratuloides, Reg. 3; (NESTED SUBCLADE 8a: C. pinarocephala, sect. Serratuloides, Reg. 3; C. crispa, sect. Serratuloides, Reg. 3). CLADE 9: C. lasiolepis, sect. Alpinae, Reg. 2, 4, 5; (NESTED SUBCLADE 9a: C. autranii, sect. Rigidissimae, Reg. 5; C. rigidissimae, sect. Rigidissimae, Reg. 5). CLADE 10: C. araneosa, sect. Cynaroideae, Reg. 2; C. linczewskii, sect. Leucocaulon, Reg. 4; C. arctotidifolia, sect. Leiocaules, Reg. 4; C. smirnowii, sect. Kopetdagia, Reg. 4; C. eryngioides, sect. Sciadocousinia, Reg. 3, 4; C. dipterocarpa, sect. Alpinae, Reg. 4; C. turkmenorum, sect. Chrysoptera, Reg. 4.; (NESTED SUBCLADE 10a: C. eriophylla, sect. Platyacanthae, Reg. 4; C. rechingerorum, sect. Platyacanthae, Reg. 4); (NESTED SUBCLADE 10b: C. apiculata, sect. Pseudactinia, Reg. 4; C. trachyphyllaria, sect. Platyacanthae, Reg. 4). CLADE 11: C. shahvarica, sect. Sphaerocephalae, Reg. 3; (NESTED SUBCLADE 11a: C. harazensis, sect. Sphaerocephalae, Reg. 3; C. xiphiolepis, sect. Sphaerocephalae, Reg. 3); (NESTED SUBCLADE 11b: C. adenosticta, sect. Sphaerocephalae, Reg. 3; C. leptolepis, sect. Sphaerocephalae, Reg. 3). CLADE 12: C. decumbens, sect. Decumbentes, Reg. 3; C. badphysi, sect. Badghysia, Reg. 4. CLADE 13: C. gatchsaranica, sect. Haussknechtii, Reg. 2; C. longifolia, sect. Spinuliferae, Reg. 4. CLADE 14: C. incompta, sect. Pugioniferae, Reg. 2; (NESTED SUBCLADE 14a: C. araneosa, sect. Cynaroideae, Reg. 2; C. purpurea, sect. Cynaroideae, Reg. 1). CLADE 15: C. tianschanica, sect. Carduncellus, Reg. 8; C. botschantzevii, sect. Regelianae, Reg. 7. 